J. Dairy Sci. 99:2221-2236

http://dx.doi.org/10.3168/jds.2015-10359

(C) 2016, THE AUTHORS. Published by FASS and Elsevier Inc. on behalf

of the American Dairy Science Association ${ }^{\circledR}$. This is an open access article under

the CC BY-NC-ND license (http://creativecommons.org/licenses/by-nc-nd/3.0/).

\title{
Effects of an individual weight-adjusted feeding strategy in early lactation on milk production of Holstein cows during extended lactation
}

\author{
C. Gaillard, ${ }^{* 1}$ N. C. Friggens, † M. Taghipoor,‡ M. R. Weisbjerg, ${ }^{*}$ J. O. Lehmann,§ and J. Sehested* \\ *Department of Animal Science, AU Foulum, Aarhus University, PO Box 50, 8830 Tjele, Denmark \\ †INRA UMR 0791, AgroParisTech UMR 079, Modélisation Systémique Appliquée aux Ruminants, 16 rue Claude Bernard, 75005 Paris, France \\ †INRA-UMR 1348 PEGASE Physiologie, Environnement et Génétique pour l'Animal et les Systèmes d'Élevage, 35590 Saint-Gilles, France \\ §Department of Agroecology, AU Foulum, Aarhus University, PO Box 50, 8830 Tjele, Denmark
}

\begin{abstract}
Extending lactation by voluntarily delaying rebreeding aims to improve fertility and milk production in the modern dairy cow. Previous studies have shown that increased energy concentrations in the ration induced greater total milk yield and lactation persistency defined by the duration and the shape of the lactation curve. In this paper, we hypothesized that increasing the supply of energy during the early lactation mobilization period would have a positive carryover effect on milk production during extended lactation. A total of 53 Holstein cows completed a 16-mo lactation, including $30 \%$ primiparous cows. The cows were divided into 2 feeding strategies: half of the cows received a highenergy density diet (HD) in early lactation followed by a lower-energy density diet (LD; strategy HD-LD). The change in diet was defined individually after 42 $\mathrm{d}$ of lactation, and when the live weight (LW) gain of the cow was $\geq 0$ based on a 5 -d average. The other half of the cows were fed the LD diet during the entire lactation (strategy LD-LD). Both groups received $3 \mathrm{~kg}$ of concentrates per day during milking. Weekly milk composition (fat, protein, lactose, and somatic cells), daily milk production, daily feed intake, daily LW, and body condition score every second week were recorded. The fda package of $\mathrm{R}$ was used to model the curves of these different variables for the 53 cows that had a lactation over $400 \mathrm{~d}$. The fitted values of these curves and the associated slopes were then compared for parity and treatment effects using a linear mixed-effects model. The HD-LD and LD-LD cows had a similar length of lactation ( $461 \pm 7 \mathrm{~d}$ ). The HD diet reduced the intensity of the mobilization period and increased the milk production of the multiparous cows in early
\end{abstract}

Received September 7, 2015.

Accepted December 2, 2015.

${ }^{1}$ Corresponding author: charlotte.gaillard@anis.au.dk lactation compared with the cows fed the LD diet. The primiparous cows used the extra energy to grow and gain weight, but not to produce more milk. After the shift in diet, the treatment had little short-term carryover effect on milk yield or LW, but it affected the slopes of some curves. From 0 to $50 \mathrm{~d}$ from shift, milk fat content of the LD-LD cows decreased faster than that of the HD-LD cows whereas milk lactose increased. From 250 to $350 \mathrm{~d}$ from shift, the energy-corrected milk decreased faster for the HD-LD cows than for the LDLD cows. The lactose content in milk decreased faster for the LD-LD cows than for the HD-LD cows, and the fat content in milk was significantly higher for the primiparous HD-LD than for the primiparous LD-LD cows. In conclusion, the supply of extra energy during the mobilization period had a 300-d negative carryover effect on lactation persistency.

Key words: extended lactation, energy balance, persistency, milk production

\section{INTRODUCTION}

The fertility of dairy cows is decreasing due to an intense in genetic selection for milk production, and the cows are often dried-off while they are still producing a high amount of milk per day (Knight, 2005). When rebreeding is voluntarily delayed, the lactation of the cows is extended beyond the traditional $10 \mathrm{mo}$, allowing a better exploitation of the capacity of the cow's production (Knight, 2005). This management also avoids the insemination occurring at the same time as the peak of production and the reconstitution of body reserves, which could improve pregnancy rates (Borman et al., 2004). The plasticity of the lactation curve offers the possibility of prolonging the lactation and increasing the persistency of the lactation (Grossman and Koops, 2003). Lactation persistency is defined as the slope of the decline in milk yield from peak lactation (Sorensen et al., 2008) and is affected by 
genetics, parity, stage of pregnancy (Nørgaard et al., 2005), milking frequency, and nutrition (Sorensen et al., 2006). Indeed, the energy density of the ration has to be adapted for each stage of the lactation, especially in early lactation, where diets with a high energy concentration can reduce the intensity of the mobilization period and lead to a higher milk production (Bossen et al., 2009). However, as cows respond individually to feeding strategies, an individual diet adjustment would improve milk production (Bossen and Weisbjerg, 2009). Even so, this individual adjustment requires a precise definition of when to adjust the diet for each cow. Our objectives in the present study were to examine the effects of an individually live weight-adjusted feeding strategy in early lactation, based on 5 consecutive daily weightings, aiming to reduce the intensity of the mobilization in early lactation, and thereby to sustain the mobilization for a longer period. It was hypothesized that an increased supply of energy during the mobilization period will have a positive carryover effect on milk production and consequently will support a planned 16-mo extended lactation.

\section{MATERIALS AND METHODS}

\section{Experimental Facilities and Animals}

The experiment was approved by The Animal Experiments Inspectorate under the Danish Veterinary and Food Administration and was carried out at the Danish Cattle Research Centre at Aarhus University, Foulum, Denmark. A total of 53 Danish Holstein cows (17 primiparous and 36 multiparous) entered the experiment 2 mo before calving from December 2012 to September 2013, and completed a 16-mo lactation and an 18-mo calving interval. Cows were housed in a loose housing system with slatted floors and cubicles with mattresses and sawdust as bedding. Cows had free access to water, automatic feed bins (RIC system, Insentec, Marknesse, the Netherlands), and an automatic milking unit (AMU; DeLaval AB, Tumba, Sweden). The AMU was equipped with a weighing platform (Danvaegt, Hinnerup, Denmark) to record the live weight (LW) of the animal at each milking and a device delivering and recording the amounts of concentrates and refusals.

\section{Experimental Design}

Before entering the experiment, cows with previous lactations were dried off 8 wk before expected calving date. Dry cows and heifers were housed on slatted floors with cubicles the first 5 wk of dry-off, on deep litter bedded with straw the next $3 \mathrm{wk}$, in a calving pen for the last 6 to $24 \mathrm{~h}$ before calving, and entered the experimental group pen immediately after calving. All cows were fed the same dry cow ration during this pre-experimental period (Table 1).

The experimental animals were blocked according to expected calving date and parity and randomly allocated to 1 of 2 feeding strategies (Table 2). In the high-low energy diet strategy (HD-LD) the cows received a partially mixed ration with a high energy density (HD), 50:50 forage:concentrate ratio, until they reached at least $42 \mathrm{~d}$ of lactation and a $\mathrm{LW}$ gain $\geq 0 \mathrm{~kg} / \mathrm{d}$ over $5 \mathrm{~d}$, on average. When these criteria were fulfilled, the cows were individually shifted to a diet with lower energy density (LD), with a 60:40 forage:concentrate ratio. The cows in the low-low energy diet strategy (LD-LD) were fed the LD diet during the whole lactation. Diets were formulated using the NORFOR model and standards (Volden, 2011). The composition of the diets is shown in Table 1. Both groups were fed the mixed part of the ration ad libitum and each cow was further offered $3 \mathrm{~kg}$ of concentrates per day in the milking robot. Weekly analyses of the dry matter content of forages were performed for adjustment of ration composition.

The cows were inseminated at the first heat observed after 220 DIM to achieve an 18-mo calving interval. Finally, the cows were dried off 8 wk before expected calving, or if the average milk production dropped below $12 \mathrm{~kg}$ of milk per cow per day in 2 subsequent weeks.

\section{Data Recording}

Feed Intake. Feed intake $(\mathrm{kg})$ was recorded for each cow at each visit to the Insentec feeder. All cows were offered a maximum of $3 \mathrm{~kg}$ of concentrate per day in the AMU. If a cow ate less than the daily $3 \mathrm{~kg}$ concentrate allowed, the amount not eaten (up to $1.5 \mathrm{~kg}$ ) was allowed on top of the $3-\mathrm{kg}$ allowance for the next day. Individual daily DMI was calculated as the sum of the partially mixed ration ingested at the Insentec and the amount of concentrate ingested at the AMU within a day.

Daily Milk Yield and Milking Frequency. The milk yield was individually recorded at each visit to the AMU. The milk yields recorded at the first and last milking of a 24-h day were divided proportionally according to time from midnight, and allocated to the days, -1 or +1 , to obtain the daily milk yield. The same adjustment was made to calculate the daily milking frequency. Individual milk samples were collected weekly by the AMU using a modified automatic sampler (XMS, DeLaval; Løvendahl and Bjerring, 2006). The milk samples were taken over a 48 -h period start- 
ing on Sunday at noon and finishing on Tuesday at the same time. The milk samples were preserved with bronopol and kept cold $\left(2^{\circ} \mathrm{C}\right)$ until they were analyzed.

$\boldsymbol{L} \boldsymbol{W}$. Individual LW was recorded 10 times per second at each AMU milking. Aberrant weight records were excluded using the procedure described in Bossen et al. (2009). The daily LW was calculated as the average of the multiple recordings.

\section{BCS}

Starting at calving, the BCS was individually scored every second week by 1 of the same 2 trained persons. A 1- to 5-point scale with 0.25 -point intervals was used where 1 represents a very lean cow and 5 a very fat cow (Ferguson et al., 1994).

\section{Chemical Analyses}

Feed. Samples of all feeds were collected weekly. Corn silage samples were composited every $6 \mathrm{wk}$, whereas barley and concentrate feed samples were composited every 3 mo. Samples were milled through a 1-mm screen before chemical analysis. Dry matter content was determined by drying in a forced-air oven at $60^{\circ} \mathrm{C}$ for 48 h. Ash was analyzed by weighing after combustion at $525^{\circ} \mathrm{C}$ (AOAC International, 2000). Crude protein was calculated based on analysis of total $\mathrm{N}$ according to the Dumas principle (Hansen, 1989) using a Vario MAX CN (Elementar Analysesysteme GmbH, Hanau, Germany). Crude fat was analyzed by Soxhlet extraction with petroleum ether after hydrolyzing with $\mathrm{HCl}$. Sugar was analyzed by the Luff-Schoorl method (European Community, 2012; 71/250/EEC). Starch was analyzed

Table 1. Ingredient composition (\% of DM) of the dry period ration, the partially mixed rations with a highenergy density (HD) and lower-energy density (LD), including the concentrates received at the automatic milking unit (AMU), and the associated chemical compositions $(\mathrm{g} / \mathrm{kg}$ of DM)

\begin{tabular}{|c|c|c|c|}
\hline Item & Diet dry period & $\mathrm{LD}+\mathrm{C}^{1}$ & $\mathrm{HD}+\mathrm{C}^{1}$ \\
\hline \multicolumn{4}{|l|}{ Ingredients, $\%$ of DM } \\
\hline Barley & - & 4.3 & 4.0 \\
\hline Wheat $\mathrm{NaOH}$ treated $^{2}$ & - & 0 & 15.8 \\
\hline Sodium bicarbonate & - & 0.5 & - \\
\hline Rapeseed cake, $10.5 \%$ fat & - & 17.2 & 15.8 \\
\hline Rapeseed meal, $4 \%$ fat & 6.4 & - & - \\
\hline Sugar beet pulp, dried & 1.5 & 8.6 & 7.9 \\
\hline Grass/clover silage & 27.8 & 31.1 & 23.7 \\
\hline Corn silage & 43.5 & 27.9 & 22.2 \\
\hline Straw (spring barley) & 19.9 & - & - \\
\hline Urea & - & 0.1 & 0.1 \\
\hline Minerals and vitamins ${ }^{3}$ & 0.9 & 0.6 & 0.6 \\
\hline Concentrates in $\mathrm{AMU}^{4}$ & - & 10.7 & 9.9 \\
\hline Forage:concentrate ratio & - & $60: 40$ & $50: 50$ \\
\hline Energy density, $\mathrm{MJ}$ of $\mathrm{NE}_{\mathrm{L}} / \mathrm{kg}$ of $\mathrm{DM}$ & - & 7.49 & 7.81 \\
\hline \multicolumn{4}{|l|}{ Chemical composition, $\mathrm{g} / \mathrm{kg}$ of $\mathrm{DM}$} \\
\hline Ash & 52 & 78 & 67 \\
\hline $\mathrm{CP}$ & 119 & 171 & 165 \\
\hline Crude fat & 27 & 45 & 44 \\
\hline Sugar & - & 47 & 45 \\
\hline Starch & 112 & 144 & 228 \\
\hline $\mathrm{NDF}$ & 481 & 337 & 305 \\
\hline $\mathrm{AAT}^{5}$ & - & 145 & 160 \\
\hline $\mathrm{PBV}^{5}$ & - & 16 & 8 \\
\hline
\end{tabular}

${ }^{1} \mathrm{LD}+\mathrm{C}$ and $\mathrm{HD}+\mathrm{C}=$ partially mixed low- or high-energy density ration + concentrates $(\mathrm{C})$ received at the AMU.

${ }^{2}$ The NaOH-treated wheat was prepared by adding $30 \mathrm{~kg}$ of $\mathrm{NaOH}$ and $100 \mathrm{~L}$ of water to 1,000 $\mathrm{kg}$ of whole wheat kernels and mixing for $10 \mathrm{~min}$.

${ }^{3}$ Minerals (per kg): $\mathrm{Ca}=203.5 \mathrm{mg}, \mathrm{Mg}=78.2 \mathrm{mg}, \mathrm{K}=0.5 \mathrm{mg}, \mathrm{Na}=0.1 \mathrm{mg}, \mathrm{Cl}=0.1 \mathrm{mg}, \mathrm{S}=12.6 \mathrm{mg}, \mathrm{I}=$ $184.2 \mathrm{mg}, \mathrm{Se}=36.8 \mathrm{mg}, \mathrm{Mn}=3,684 \mathrm{~g}, \mathrm{Zn}=5,263 \mathrm{~g}, \mathrm{Co}=26.3 \mathrm{mg}, \mathrm{Cu}=1,052 \mathrm{mg}$. Vitamins (per kg): $\mathrm{A}=$ $526 \mathrm{kIU}, \mathrm{D}_{3}=116 \mathrm{kIU}, \alpha$-tocopherol $=2,874 \mathrm{mg}, \mathrm{E}=3,158 \mathrm{IU}$.

${ }^{4}$ Composition of the concentrates in milking robot (\% DM): $16.9 \%$ sugar beet pulp, dried; $16.8 \%$ rapeseed meal; $14.6 \%$ barley; $14.6 \%$ wheat; $9.0 \%$ soybean meal, dehulled; $7.0 \%$ sunflower meal, dehulled; $7.0 \%$ citrus pulp, dried; $5.0 \%$ wheat bran; $5.0 \%$ alfalfa meal; $3.0 \%$ molasses, cane; $0.7 \%$ sodium chloride; $0.3 \%$ mineral premix; $0.1 \%$ magnesium oxide. Minerals (per $\mathrm{kg}$ ): $\mathrm{Fe}=59 \mathrm{mg}, \mathrm{Zn}=46 \mathrm{mg}, \mathrm{Mn}=38 \mathrm{mg}, \mathrm{Cu}=8 \mathrm{mg}, \mathrm{I}=0.7 \mathrm{mg}, \mathrm{Se}$ $=0.30 \mathrm{mg}, \mathrm{Co}=0.11 \mathrm{mg}$. Vitamins (per kg): $\mathrm{A}=1,000 \mathrm{IU}, \mathrm{D}_{3} 1,000 \mathrm{IU}, \alpha$-tocopherol $=45 \mathrm{mg}, \mathrm{E}=50 \mathrm{mg}$. ${ }^{5} \mathrm{AAT} / \mathrm{PBV}=$ protein evaluation system for ruminants used in the Nordic countries. AAT represents the amino acids absorbed in the small intestine and PBV the protein balance in the rumen (Volden, 2011). 
Table 2. Cow characteristics and effects of feeding treatment and parity on milking frequency, ECM, milk, fat, protein, lactose, SCS, live weight (LW), BCS, DMI, net energy intake, and energy balance (EB) (means \pm SEM)

\begin{tabular}{|c|c|c|c|c|c|c|c|c|}
\hline \multirow[b]{2}{*}{ Item } & \multicolumn{2}{|c|}{ Primiparous } & \multicolumn{2}{|c|}{ Multiparous } & \multirow[b]{2}{*}{ SEM } & \multicolumn{3}{|c|}{$P$-value ${ }^{1}$} \\
\hline & $\mathrm{LD}-\mathrm{LD}^{2}$ & $\mathrm{HD}-\mathrm{LD}^{3}$ & $\mathrm{LD}_{-} \mathrm{LD}^{2}$ & $\mathrm{HD}-\mathrm{LD}^{3}$ & & $\mathrm{~T}$ & $\mathrm{P}$ & $\mathrm{T} \times \mathrm{P}$ \\
\hline \multicolumn{9}{|l|}{ Characteristics } \\
\hline Number of animals & 9 & 8 & 18 & 18 & - & - & - & - \\
\hline Duration of lactation, d & 464 & 463 & 462 & 454 & 12 & 0.55 & 0.60 & 0.74 \\
\hline Pregnancy time, DIM & 242 & 252 & 242 & 228 & 15 & 0.27 & 0.58 & 0.21 \\
\hline Total milk yield, kg & 14,565 & 12,928 & 15,671 & 15,928 & 901 & 0.70 & 0.02 & 0.25 \\
\hline \multicolumn{9}{|c|}{ Means before the shift ( 0 to 42 DIM) } \\
\hline Milking frequency & 2.4 & 2.6 & 3.1 & 3.4 & 0.2 & 0.11 & $<0.01$ & 0.80 \\
\hline ECM, $\mathrm{kg} / \mathrm{d}$ & 32.5 & 28.9 & 40.1 & 42.9 & 1.5 & 0.41 & $<0.01$ & 0.02 \\
\hline Milk 0-7 DIM, kg/d & 21.1 & 17.9 & 28.0 & 30.2 & 1.4 & 0.71 & $<0.01$ & 0.02 \\
\hline Milk 35-42 DIM, kg/d & 34.3 & 30.7 & 42.6 & 46.8 & 1.8 & 0.18 & $<0.01$ & 0.02 \\
\hline Fat, $\%$ & 4.59 & 4.53 & 4.49 & 4.11 & 0.10 & 0.02 & 0.06 & 0.21 \\
\hline Protein, \% & 3.34 & 3.37 & 3.42 & 3.38 & 0.07 & 0.72 & 0.47 & 0.51 \\
\hline Lactose, $\%$ & 4.89 & 4.95 & 4.81 & 4.84 & 0.03 & 0.18 & $<0.01$ & 0.74 \\
\hline SCS, $\log ($ cells $)$ & 1.87 & 1.98 & 1.98 & 2.09 & 0.07 & 0.17 & 0.21 & 0.96 \\
\hline LW at calving, kg & 613 & 602 & 658 & 692 & 13 & 0.54 & $<0.01$ & 0.13 \\
\hline LW at 42 DIM, kg & 559 & 574 & 629 & 678 & 11 & 0.05 & $<0.01$ & 0.21 \\
\hline $\mathrm{BCS}$ & 3.08 & 3.19 & 3.11 & 3.20 & 0.03 & 0.01 & 0.68 & 0.85 \\
\hline DMI, $\mathrm{kg}$ of $\mathrm{DM} / \mathrm{d}$ & 15.5 & 15.1 & 20.0 & 21.1 & 0.6 & 0.13 & $<0.01$ & 0.16 \\
\hline Energy intake, MJ of $\mathrm{NE}_{\mathrm{L}} / \mathrm{d}$ & 116 & 118 & 149 & 164 & 5 & $<0.01$ & $<0.01$ & 0.09 \\
\hline $\mathrm{EB}, \mathrm{MJ}$ of $\mathrm{NE}_{\mathrm{L}} / \mathrm{d}$ & -25.1 & -11.3 & -19.7 & -13.8 & 4.2 & 0.01 & 0.66 & 0.27 \\
\hline \multicolumn{9}{|c|}{ Means after the shift (0 DFS to the end of the lactation) } \\
\hline Milking frequency & 2.3 & 2.4 & 2.5 & 2.6 & 0.1 & 0.59 & 0.19 & 0.80 \\
\hline $\mathrm{ECM}, \mathrm{kg} / \mathrm{d}$ & 31.8 & 29.7 & 32.9 & 33.3 & 1.4 & 0.76 & 0.08 & 0.33 \\
\hline Milk, kg/d & 31.4 & 27.8 & 32.6 & 32.9 & 1.5 & 0.48 & 0.02 & 0.13 \\
\hline Fat, $\%$ & 4.07 & 4.48 & 4.18 & 4.12 & 0.12 & 0.45 & 0.37 & 0.08 \\
\hline Protein, \% & 3.61 & 3.64 & 3.56 & 3.56 & 0.04 & 0.94 & 0.27 & 0.78 \\
\hline Lactose, $\%$ & 4.87 & 4.87 & 4.82 & 4.73 & 0.02 & 0.05 & 0.01 & 0.19 \\
\hline SCS, $\log ($ cells $)$ & 1.87 & 1.88 & 1.97 & 2.12 & 0.11 & 0.21 & 0.09 & 0.48 \\
\hline $\mathrm{LW}$ at $0 \mathrm{DFS},{ }^{4} \mathrm{~kg}$ & 567 & 575 & 627 & 663 & 12 & 0.16 & $<0.001$ & 0.37 \\
\hline LW at 300 DFS, kg & 689 & 675 & 726 & 757 & 19 & 0.49 & 0.01 & 0.34 \\
\hline BCS & 3.24 & 3.35 & 3.30 & 3.37 & 0.04 & 0.11 & 0.42 & 0.72 \\
\hline DMI, $\mathrm{kg}$ of DM/d & 21.1 & 19.9 & 23.8 & 24.0 & 0.6 & 0.78 & $<0.001$ & 0.13 \\
\hline Energy intake, MJ of $\mathrm{NE}_{\mathrm{L}} / \mathrm{d}$ & 164 & 153 & 179 & 181 & 4.7 & 0.64 & $<0.001$ & 0.14 \\
\hline $\mathrm{EB}, \mathrm{MJ}$ of $\mathrm{NE}_{\mathrm{L}} / \mathrm{d}$ & 16.6 & 13.4 & 20.1 & 18.9 & 2.8 & 0.43 & 0.06 & 0.68 \\
\hline
\end{tabular}

${ }^{1} \mathrm{~T}=$ treatment; $\mathrm{P}=$ parity; $\mathrm{T} \times \mathrm{P}=$ interaction.

${ }^{2} \mathrm{LD}-\mathrm{LD}=$ group with 1 partially mixed ration 60:40 forage:concentrate during the entire lactation.

${ }^{3} \mathrm{HD}-\mathrm{LD}=$ group with 2 partially mixed rations 50:50 followed by 60:40 forage:concentrate when LW gain $\geq 0$ and at least after 42 DIM.

${ }^{4} \mathrm{DFS}=$ days from shift.

by an enzymatic colorimetric technique (Knudsen et al., 1987). The NDF content was analyzed by neutral detergent extraction (Mertens et al., 2002) using a Fibertec M6 System (Foss Analytical, Hillerød, Denmark). The chemical composition of mixed rations is presented in Table 1.

Milk Components. Milk samples were analyzed weekly using mid-infrared spectroscopy (Eurofins, Aarhus, Denmark) for the percentages of fat, protein, lactose, and SCC; the SCC data were log-transformed to give the SCS.

\section{Data Analysis}

Calculation of ECM. Energy-corrected milk (3.140 $\mathrm{MJ} / \mathrm{kg}$ ) was calculated according to Sjaunja's equation (Sjaunja et al., 1991):

$$
\begin{aligned}
\mathrm{ECM}= & \text { milk yield } \times[(38.3 \times \text { fat }+24.2 \times \text { protein } \\
& +15.71 \times \text { lactose }+20.7) / 3.140],
\end{aligned}
$$

with ECM and milk yield in kilograms, and fat, protein, and lactose in grams per kilogram.

Calculation of Energy Balance. Daily energy balance (EB; MJ of $\mathrm{NE}_{\mathrm{L}} / \mathrm{d}$ ) was calculated using the following basic equation:

$$
\mathrm{EB}=\mathrm{E}_{\text {intake }}-\left(\mathrm{E}_{\text {lact }}+\mathrm{E}_{\text {maint }}+\mathrm{E}_{\text {act }}\right)
$$

where $\mathrm{E}_{\text {lact }}=\mathrm{ECM} \times 3.14, \mathrm{E}_{\text {maint }}=\mathrm{LW}^{0.75} \times 0.08 \times \mathrm{a}$, and $\mathrm{E}_{\text {act }}=\mathrm{LW} \times 0.01 \times \mathrm{b}$. The $\mathrm{E}_{\text {intake }}$ is the total energy intake (MJ of $\mathrm{NE}_{\mathrm{L}} / \mathrm{d}$ ). The $\mathrm{E}_{\text {lact }}$ is the energy output with milk (MJ of $\mathrm{NE}_{\mathrm{L}} / \mathrm{d}$ ) calculated by multiplying the ECM (kg/d) by $3.140 \mathrm{MJ} / \mathrm{kg}$ (Sjaunja et al., 1991). 
The $\mathrm{E}_{\text {maint }}$ is the energy required for maintenance (MJ of $\left.\mathrm{NE}_{\mathrm{L}} / \mathrm{d}\right)$, calculated by multiplying the $\mathrm{LW}(\mathrm{kg})$ by $0.08 \mathrm{Mcal} / \mathrm{kg} / \mathrm{d}$ (NRC, 2001), and a is the coefficient of conversion from megacalories to megajoules, equal to 4.184. The $\mathrm{E}_{\text {act }}$ is the energy required for the activity of loose housed cows (MJ of $\mathrm{NE}_{\mathrm{L}} / \mathrm{d}$ ) which is considered to be $10 \%$ of the LW (0.01 MJ of ME/kg; NRC, 2001), and $b$ is the coefficient of conversion from $\mathrm{ME}$ to $\mathrm{NE}_{\mathrm{L}}$, equal to 0.65. The energy used for growth (only for the first and second parity), and the energy used for conception were not included, as they have been shown to be less than $1 \%$ of the energy output (Friggens et al., 2007).

Smoothing with the ' $f d a$ ' Package. The functional data analysis (fda) package of $\mathrm{R}$ (Ramsay et al., 2010) was chosen to smooth our daily production data, as it can be applied for all our production data whatever the shape of their curves. A single common equation, such as the Wood function (Wood, 1967), which is often used to describe lactation curves, would not fit our extended lactation data because the shapes of the curves were longer than the traditional 10-mo lactation and varied according to parity and the treatment of our cows. Moreover, it could not be applied to all the other performance data. Polynomials could have been a solution to fit all our data the same way, but in this case all the points of the smoothed curves should have been correlated leading to a decrease in quality of the information. With the fda method, only local correlations exist between points because of the knots which provide independence of fitting for data that are separated by 3 knots, in this case 3 DIM. Moreover, the smoothed data allowed us to calculate the slopes of the curves as the derivative of the smoothed data, at any day, even without raw data at this precise time. This allowed easy comparison of the shape of the curves
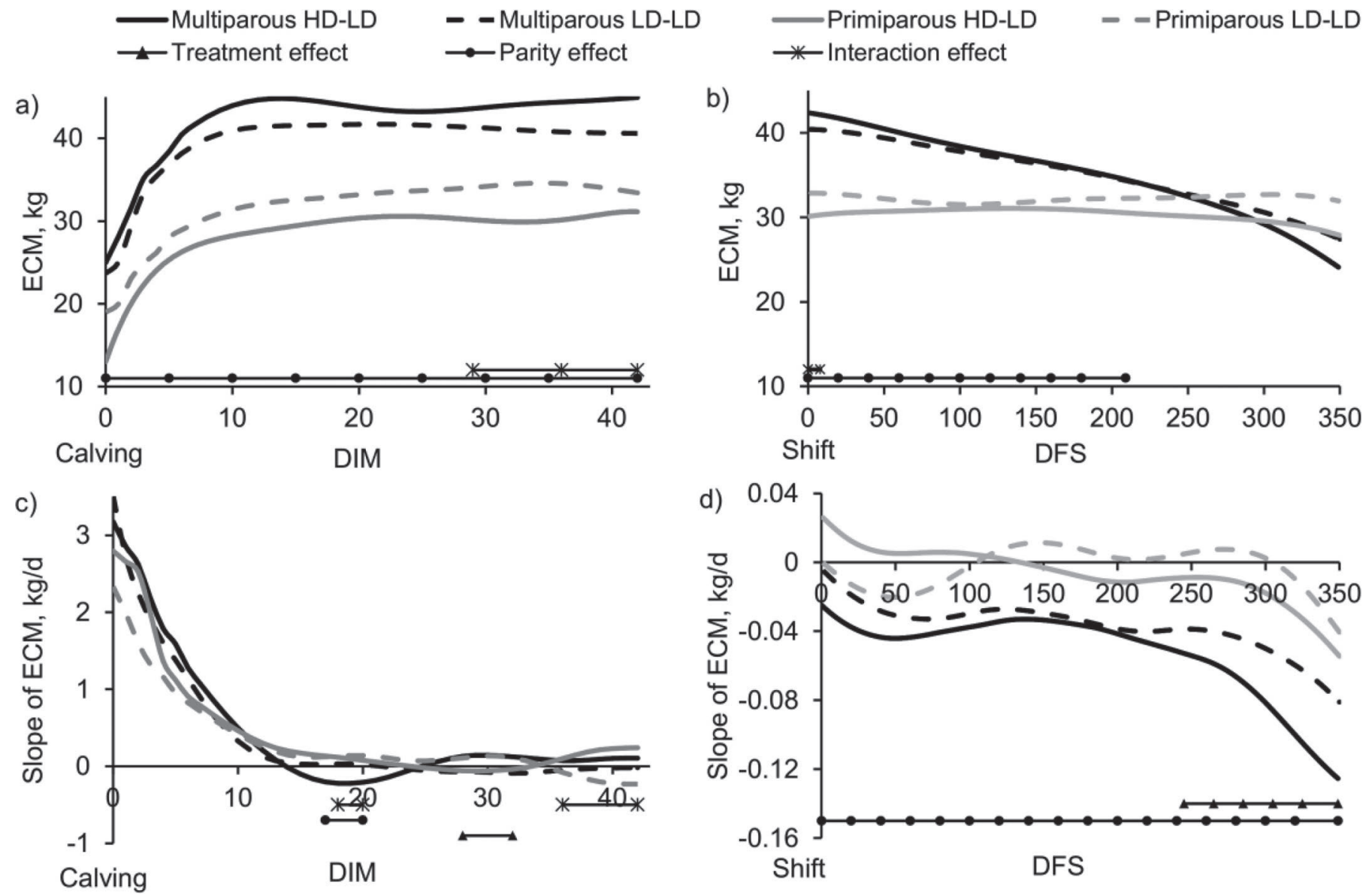

Figure 1. Smoothed ECM (kg/d) and associated slopes from calving to 42 DIM (a and c, respectively), and after the shift back to a common diet for all cows [days from shift (DFS) =0] until 350 DFS (b and d, respectively), according to treatment (full line HD-LD, dashed line LDLD) and parity (black multiparous, gray primiparous). The days on which the effects of treatment, parity, and their interaction are significant $(P<0.05)$ are indicated by the horizontal bars on the graphs. LD-LD = group with 1 partially mixed ration 60:40 forage:concentrate during the entire lactation. HD-LD = group with 2 partially mixed rations 50:50 followed by 60:40 forage:concentrate when live weight gain $\geq 0$ and at least after 42 DIM. 
between groups, and it was one of the main interests of the current study. Indeed, the slopes are key indicators to study milk production in dairy cows. For the ECM curve, the slope represents the persistency of the lactation, as it has been defined as the rate of decline in milk yield from the peak yield by several previous studies (Pettersson et al., 2011). For the other variables studied, the slopes represent the rate of decay of an initial difference.

The smoothing with the fda package uses a B-spline basis function and does not require assumptions about the shape of the lactation curve. This last point was an important advantage, as we worked with longer lactations and changes in energy supply. The spline functions of the fda package are constructed by joining polynomials end-to-end at argument values called knots (in our case, the knots are the DIM). These spline functions are smoothing on the integral of the squared deviations from an arbitrary differential operator. The degree of smoothing can be adjusted by applying a penalty on the derivative(s) of the functions. In the present paper, a penalty of $1 \mathrm{e}^{+6}$ was applied to the second derivatives of polynomials of order 4 . With this penalty, the required level of smoothing was achieved and fitted the lactation peak and the following part of the lactation. However, the first week after calving, milk production was overestimated for most cows; therefore, a penalty of $1 \mathrm{e}^{+2}$ was also used to fit the individual curves and to fit the first weeks of the lactation properly. The smoothed data and associated sloped obtained with the penalty of $1 \mathrm{e}^{+2}$ were kept to study the period from calving to 42 DIM, whereas the one obtained with the penalty of $1 \mathrm{e}^{+6}$ were kept to study the postshift period from the day from shift (DFS) to late lactation (350 DFS).
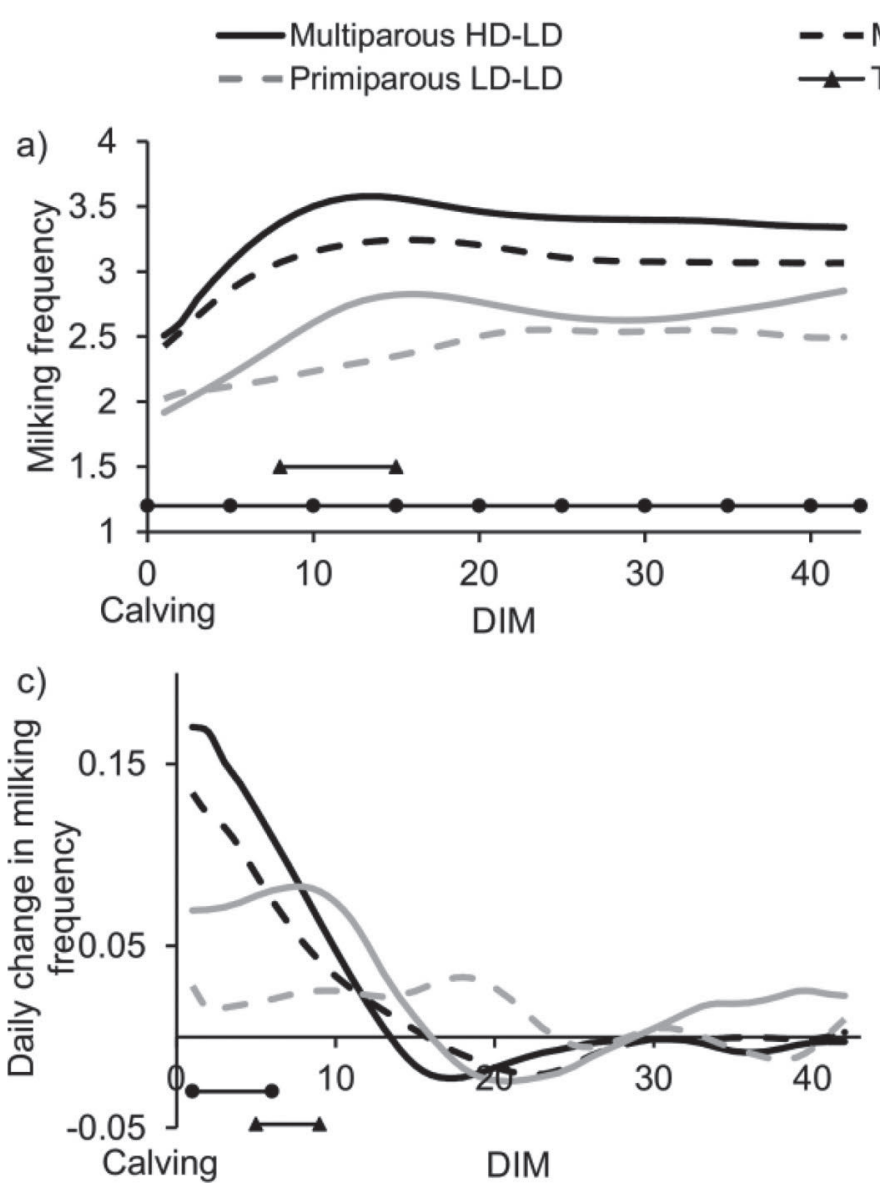
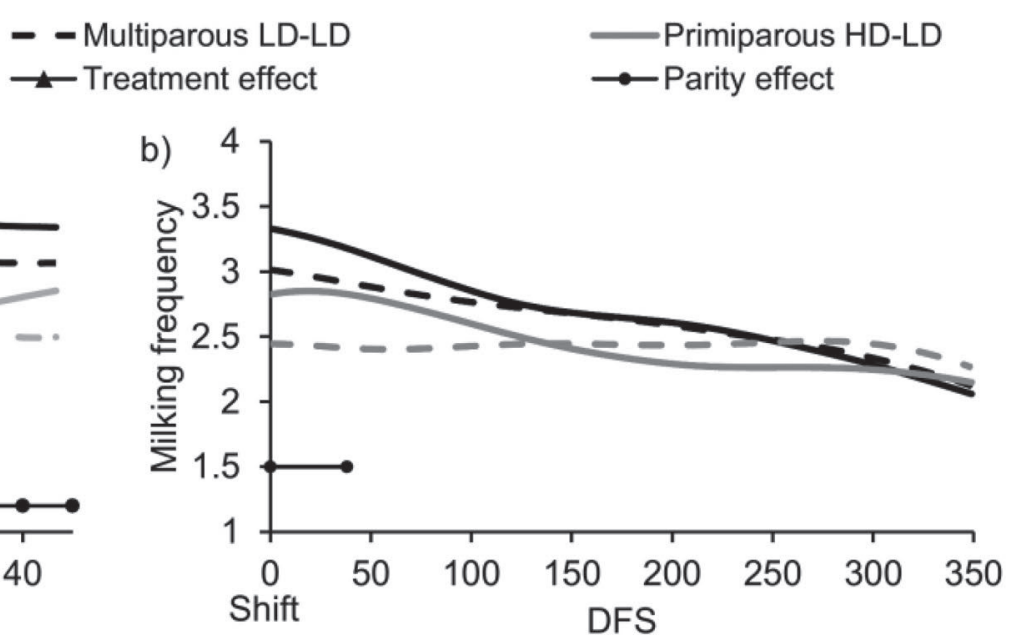

d)

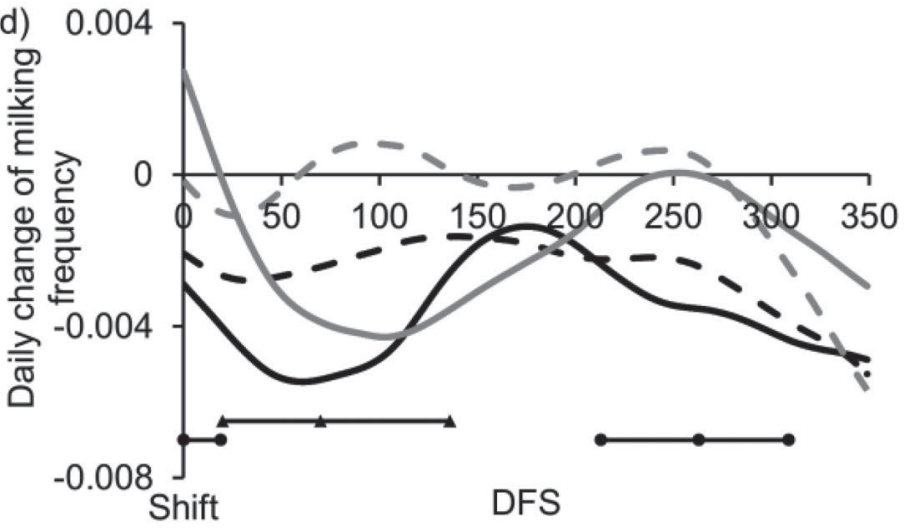

Figure 2. Smoothed milking frequency and associated slopes from calving to 42 DIM (a and c, respectively), and after the shift back to a common diet for all cows [days from shift (DFS) = 0] until 350 DFS (b and d, respectively), according to treatment (full line HD-LD, dash line LD-LD) and parity (black multiparous, gray primiparous). The days on which the effects of treatment, parity, and their interaction are significant $(P<0.05)$ are indicated by the horizontal bars on the graphs. LD-LD = group with 1 partially mixed ration 60:40 forage:concentrate during the entire lactation. HD-LD = group with 2 partially mixed rations 50:50 followed by 60:40 forage:concentrate when live weight gain $\geq 0$ and at least after 42 DIM. 


\section{Statistical Analysis}

The effects of treatment and parity on the smoothed daily $\mathrm{ECM}(\mathrm{kg} / \mathrm{d}), \mathrm{LW}(\mathrm{kg}), \mathrm{BCS}$ (point), DMI $(\mathrm{kg}$ of $\mathrm{DM} / \mathrm{d}$ ), net energy intake (MJ of $\mathrm{ME} / \mathrm{d}$ ), fat (\%), protein (\%), lactose (\%), SCS, milking frequency, and associated slopes were analyzed with $\mathrm{R}$ software version 3.0.0 (R Development Core Team, 2015). The lme function from the nlme package (Pinheiro et al., 2015) was used to fit the linear mixed-effects model (Laird and Ware, 1982) described below:

$$
\mathrm{Y}_{\mathrm{ijl}}=\mu+\mathrm{T}_{\mathrm{i}}+\mathrm{P}_{\mathrm{j}}+(\mathrm{TP})_{\mathrm{ij}}+\mathrm{C}_{\mathrm{ijl}}+\varepsilon_{\mathrm{ijl}}
$$

where $\mu$ is the overall mean, and the model includes the effects of the ith feeding treatment T ( $\mathrm{i}=\mathrm{LD}-\mathrm{LD}, \mathrm{HD}-$ $\mathrm{LD})$, the jth parity $\mathrm{P}(\mathrm{j}=$ primiparous, multiparous $)$,
$(\mathrm{TP})_{\mathrm{ij}}$ denotes the 2-way interaction, $\mathrm{C}_{\mathrm{ijl}}$ is the random effect of the lth cow within i treatment and $\mathrm{j}$ parity, and $\varepsilon_{\mathrm{ijl}}$ is the residual error.

The model was applied to each day of the 2 periods studied from 0 to $42 \mathrm{DIM}$ and from 0 to 350 DFS. The effect of the day was not included directly in the model because of the highly correlated nature of smoothed data. The effects of parity and treatment were determined for each day to understand the possible carryover and duration of the HD diet on the production variables during mid and late lactation. Figures 1 to 10 present the results for the 2 periods studied, indicating when the effects of parity, treatment, and interaction were significant. Averages of ECM $(\mathrm{kg} / \mathrm{d}), \mathrm{LW}(\mathrm{kg})$, BCS (point), DMI ( $\mathrm{kg} \mathrm{DM} / \mathrm{d})$, net energy intake (MJ of $\mathrm{ME} / \mathrm{d}$ ), fat (\%), protein (\%), lactose (\%), SCS, and milking frequency were also calculated using raw data, and are given in Table 2 for the 2 periods studied.

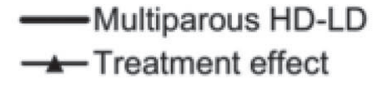

a)

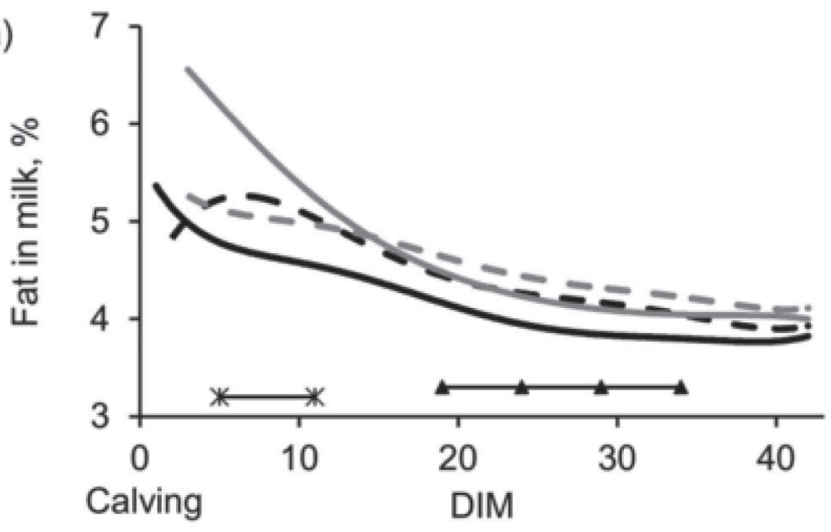

c)
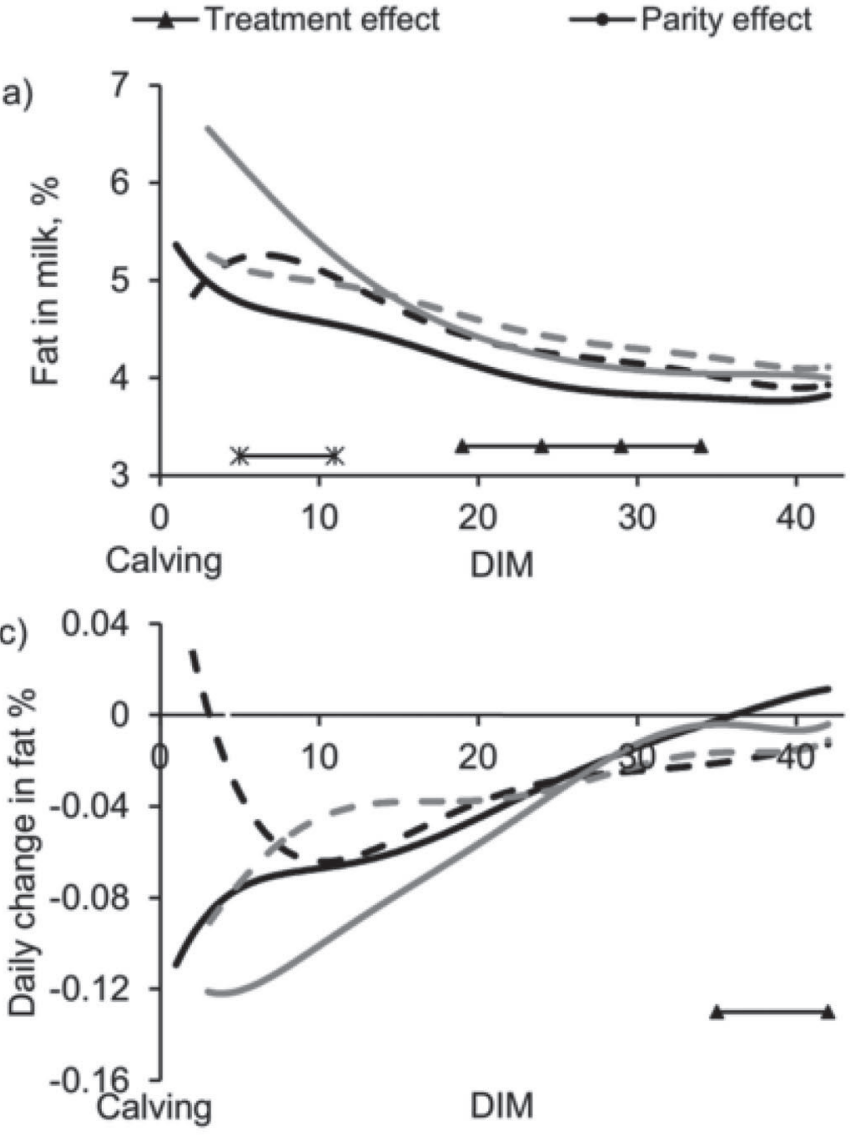

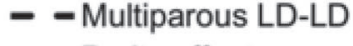

b)
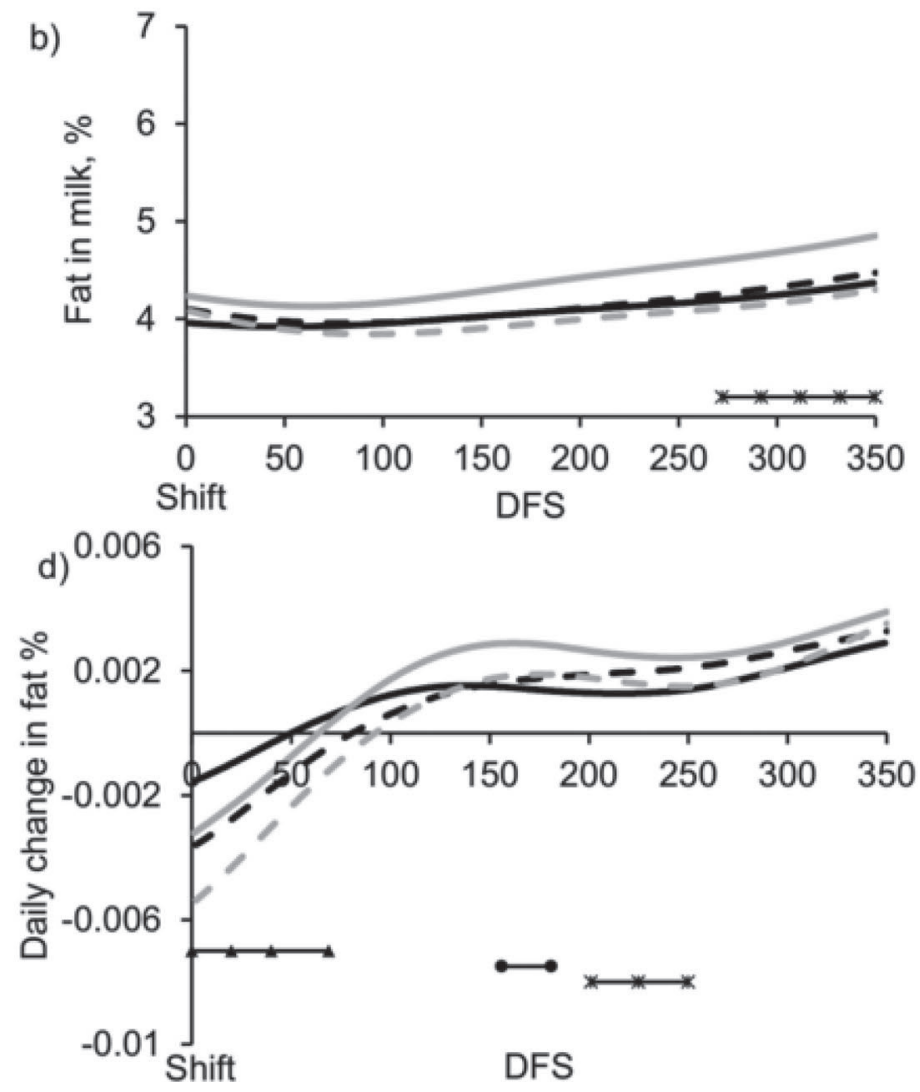

Figure 3. Smoothed fat in milk (\%) and associated slopes from calving to 42 DIM (a and c, respectively), and after the shift back to a common diet for all cows [days from shift (DFS) $=0$ ] until 350 DFS (b and d, respectively), according to treatment (full line HD-LD, dash line LD-LD) and parity (black multiparous, gray primiparous). The days on which the effects of treatment, parity, and their interaction are significant $(P<0.05)$ are indicated by the horizontal bars on the graphs. LD-LD = group with 1 partially mixed ration 60:40 :concentrate during the entire lactation. HD-LD = group with 2 partially mixed rations 50:50 followed by 60:40 forage:concentrate when live weight gain $\geq 0$ and at least after 42 DIM. 


\section{RESULTS}

\section{Lactation Duration and Total Milk Yield}

The 53 Holstein cows had an average ( \pm SEM) lactation length of $461 \pm 7 \mathrm{~d}$ regardless of the feeding treatment $(P=0.60)$ and the parity $(P=0.55)$. Total milk yield was not influenced by treatment $(P=0.70)$, and primiparous cows had a lower total milk yield than multiparous $(P=0.02,13,746$ and $15,799 \mathrm{~kg}$, respectively; Table 2).

\section{Before the Diet Shift}

Table 2 shows the means of the production variables before the shift in diet from calving to 42 DIM. Figures 1 to 10 present the smoothed data (a) and associated curves (c) for the production variables from calving to 42 DIM.
The DMI was similar for the LD-LD and HD-LD cows $(P=0.13)$ and higher for multiparous cows than primiparous cows $(P<0.001)$. The net energy intake was greater for the HD-LD than the LD-LD cows $(P=$ $0.002)$ and greater for multiparous than primiparous $(P$ $<0.001)$. The EB was less negative for the HD-LD cows than for the LD-LD cows (-12 vs. $-22 \mathrm{MJ}$ of $\mathrm{NE}_{\mathrm{L}} / \mathrm{d}$ respectively, $P=0.01)$. The $\mathrm{BCS}$ was higher for the HD-LD than the LD-LD cows $(P=0.01)$, but similar regarding parity. The LW at calving was similar for both treatments $(P=0.54)$, but higher for the HD-LD cows at $42 \operatorname{DIM}(P=0.05)$. The LW was always higher for multiparous compared with primiparous $(P<0.001)$. From 0 to 42 DIM, an interaction between treatment and parity for ECM was noted $(P=0.02)$, showing that the primiparous LD-LD had a higher ECM than the primiparous HD-LD whereas multiparous LD-LD had a lower ECM than multiparous HD-LD. However,
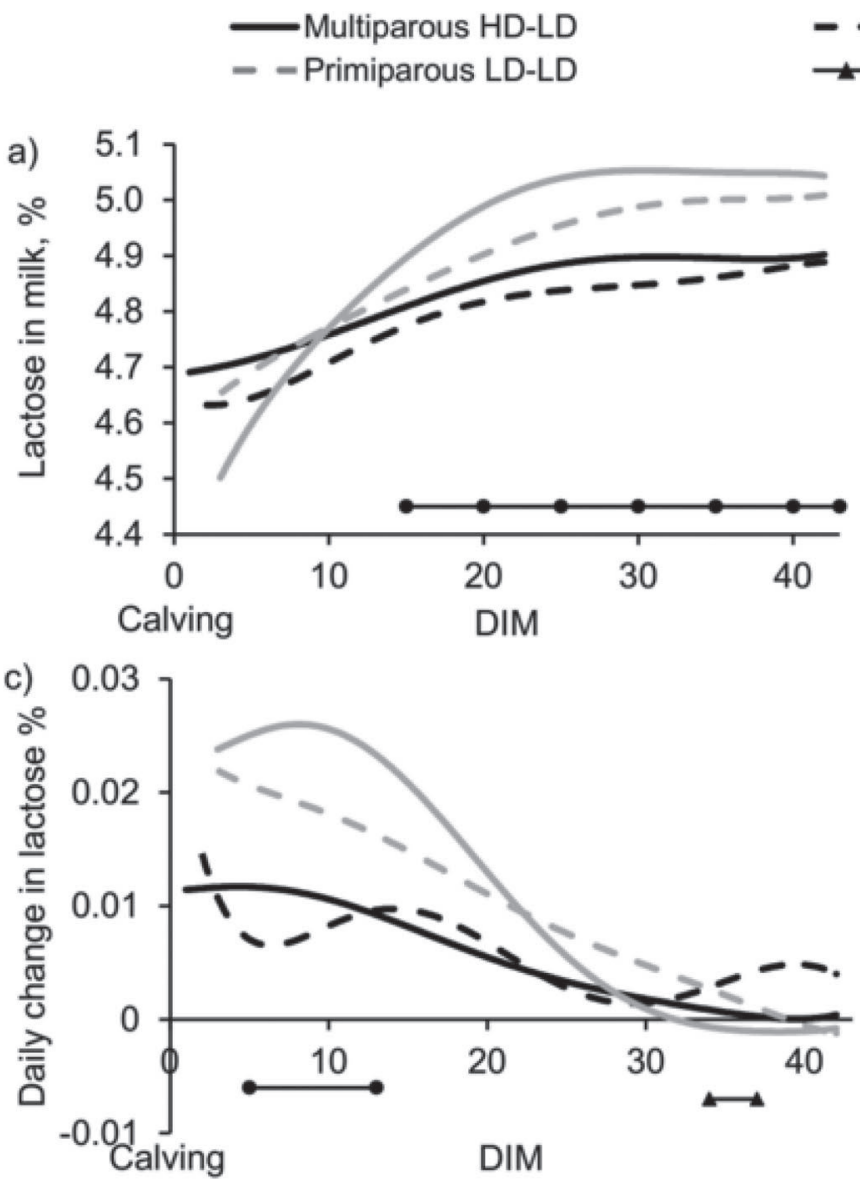
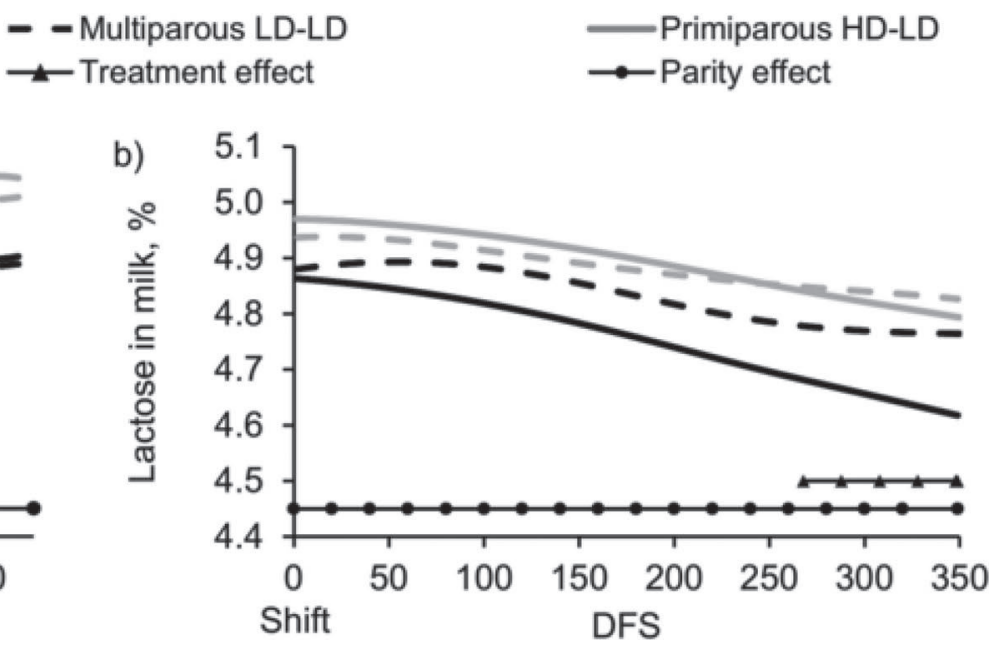

d)

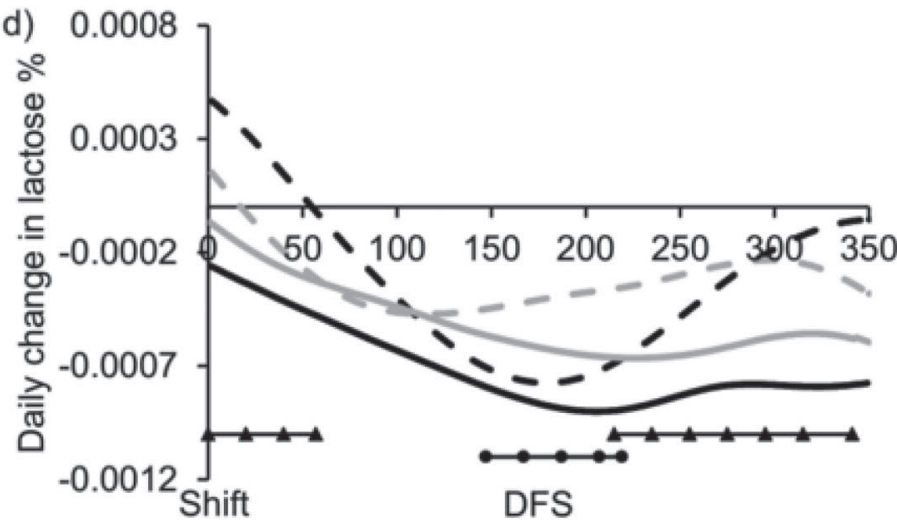

Figure 4. Smoothed lactose in milk (\%) and associated slopes from calving to 42 DIM (a and c, respectively), and after the shift back to a common diet for all cows [days from shift (DFS) =0] until 350 DFS (b and d, respectively), according to treatment (full line HD-LD, dash line LD-LD) and parity (black multiparous, gray primiparous). The days on which the effects of treatment, parity, and their interaction are significant $(P<0.05)$ are indicated by the horizontal bars on the graphs. LD-LD = group with 1 partially mixed ration 60:40 forage:concentrate during the entire lactation. HD-LD = group with 2 partially mixed rations 50:50 followed by 60:40 forage:concentrate when live weight gain $\geq 0$ and at least after 42 DIM. 
this interaction was present from the start of the trial, as looking at the milk yield during the first week after calving (from 0 to 7 DIM) showed the same interaction $(P=0.02)$. There was no effect of treatment on the milking frequency $(P=0.11)$. The multiparous cows had more daily milkings than the primiparous (3.2 vs. $2.5 \pm 0.1$ respectively, $P<0.001$ ). For the same period, the milk fat was lower for the HD-LD cows than for the LD-LD cows $(P=0.02)$, and no significant difference between treatments was found for the other milk components. An effect of parity was found only on milk lactose $(P=0.008)$, where primiparous cows had a higher lactose than multiparous cows. Regarding the slopes, the HD-LD cows had a faster increase of DMI from calving to 10 DIM compared with the LD-LD cows. No effect of the feeding treatment was observed on the EB, LW, BCS, ECM, milking frequency, and milk components slopes.

\section{After the Diet Shift}

Table 2 shows the means of the production variables after the shift in diet from the shift (0 DFS) to the end of the lactation. During this period, the feeding treatment had no effect on our production variables. The primiparous had a lower daily milk yield, LW, DMI, energy intake, and higher lactose in milk than the multiparous cows. Figures 1 to 10 present the smoothed data (b) and associated curves (d) for the production variables from 0 to 350 DFS.

$\boldsymbol{E} \boldsymbol{C M}$. From 0 to $200 \mathrm{DFS}$, the primiparous cows produced less ECM than the multiparous cows (Figure 1). The first $8 \mathrm{~d}$ following the shift, an interaction between parity and treatment was noted where the multiparous HD-LD produced more milk than the multiparous LD-LD, whereas the primiparous HD-LD produced less milk than the primiparous LD-LD.

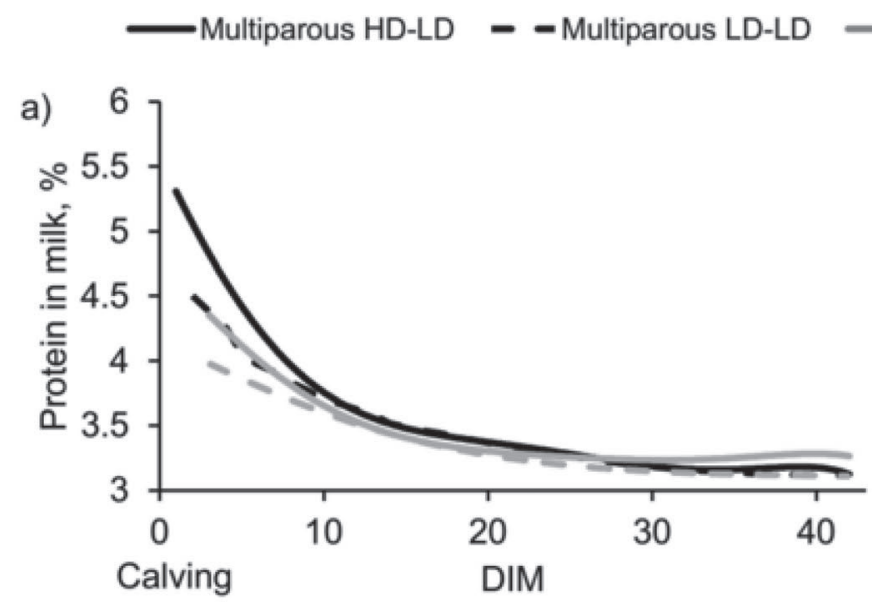

-Primiparous HD-LD $\quad--$ Primiparous LD-LD $\rightarrow-$ Parity effect
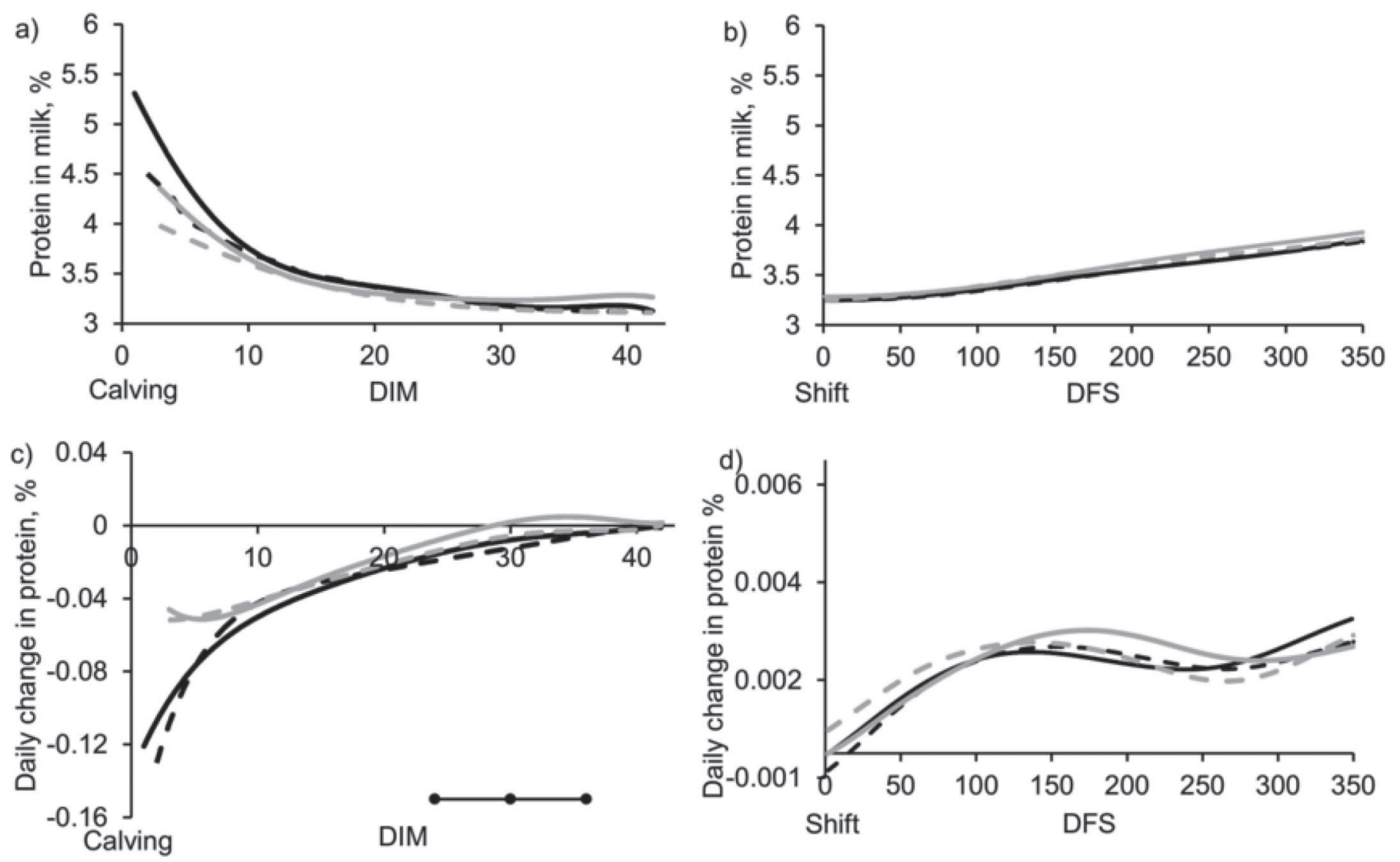

Figure 5. Smoothed protein in milk (\%) and associated slopes from calving to 42 DIM (a and c, respectively), and after the shift back to a common diet for all cows [days from shift (DFS) =0] until 350 DFS (b and d, respectively), according to treatment (full line HD-LD, dash line LD-LD) and parity (black multiparous, gray primiparous). The days on which the effects of treatment, parity, and their interaction are significant $(P<0.05)$ are indicated by the horizontal bars on the graphs. LD-LD = group with 1 partially mixed ration 60:40 forage:concentrate during the entire lactation. HD-LD = group with 2 partially mixed rations 50:50 followed by 60:40 forage:concentrate when live weight gain $\geq 0$ and at least after 42 DIM. 
The shapes of the ECM curves differed between parities from 0 to 350 DFS. The primiparous cows had a flat curve with slopes around zero, whereas the multiparous had a decreasing curve and, thus, an increasingly negative slope. Moreover, the treatment had a late effect on the slopes of ECM from 250 to 300 DFS. The ECM of the HD-LD cows decreased faster than the ECM of the LD-LD cows regardless the parity.

Daily Milking Frequency. The treatment had no effect on the milking frequency (Figure 2), but the slopes of the groups were different from 20 to 140 DFS where the milking frequency decreased faster over days for the HD-LD cows than for the LD-LD cows. From 0 to 40 DFS, the primiparous cows had fewer milkings than multiparous cows (2.6 vs. $3.1 \pm 0.2$ milkings per day, respectively, at $20 \mathrm{DFS}, P=0.10)$. Parity also had an effect on the slopes of the curves of number of milkings from 0 to 20 DFS and from 200 to 300 DFS, the milking frequency decreased faster for the primiparous than for the multiparous cows.

Milk Components. After 270 DFS, the primiparous HD-LD cows had a higher fat in milk than the primiparous LD-LD cows, whereas the multiparous HD-LD cows had lower fat in milk than the multiparous LD-LD cows. Treatment had an effect on the shape of the curves from 0 to $60 \mathrm{DFS}$, where the fat in milk decreased faster for the LD-LD cows than for the HD-LD cows (Figure 3). From 0 to 350 DFS, the primiparous cows had higher lactose in milk than the multiparous cows. From 240 to 350 DFS, the HD-LD cows had less lactose in milk than the LD-LD cows. Moreover, from 0 to 50 and from 200 to 350 DFS, the lactose in milk of the HD-LD cows decreased faster than that of the LD-LD cows (Figure 4). No effect of treatment or parity was noted on the protein in milk and on the associated slopes (Figure 5). From 270 DFS

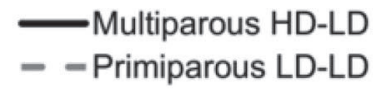

a)
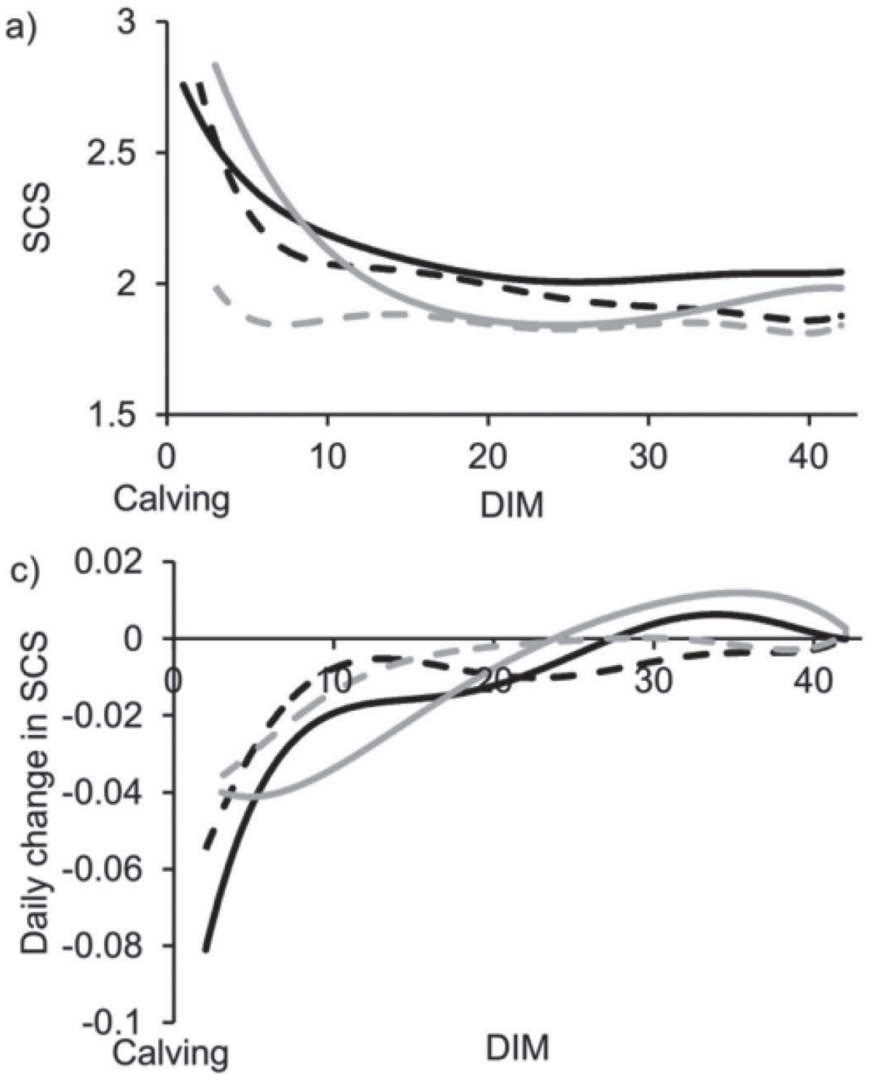
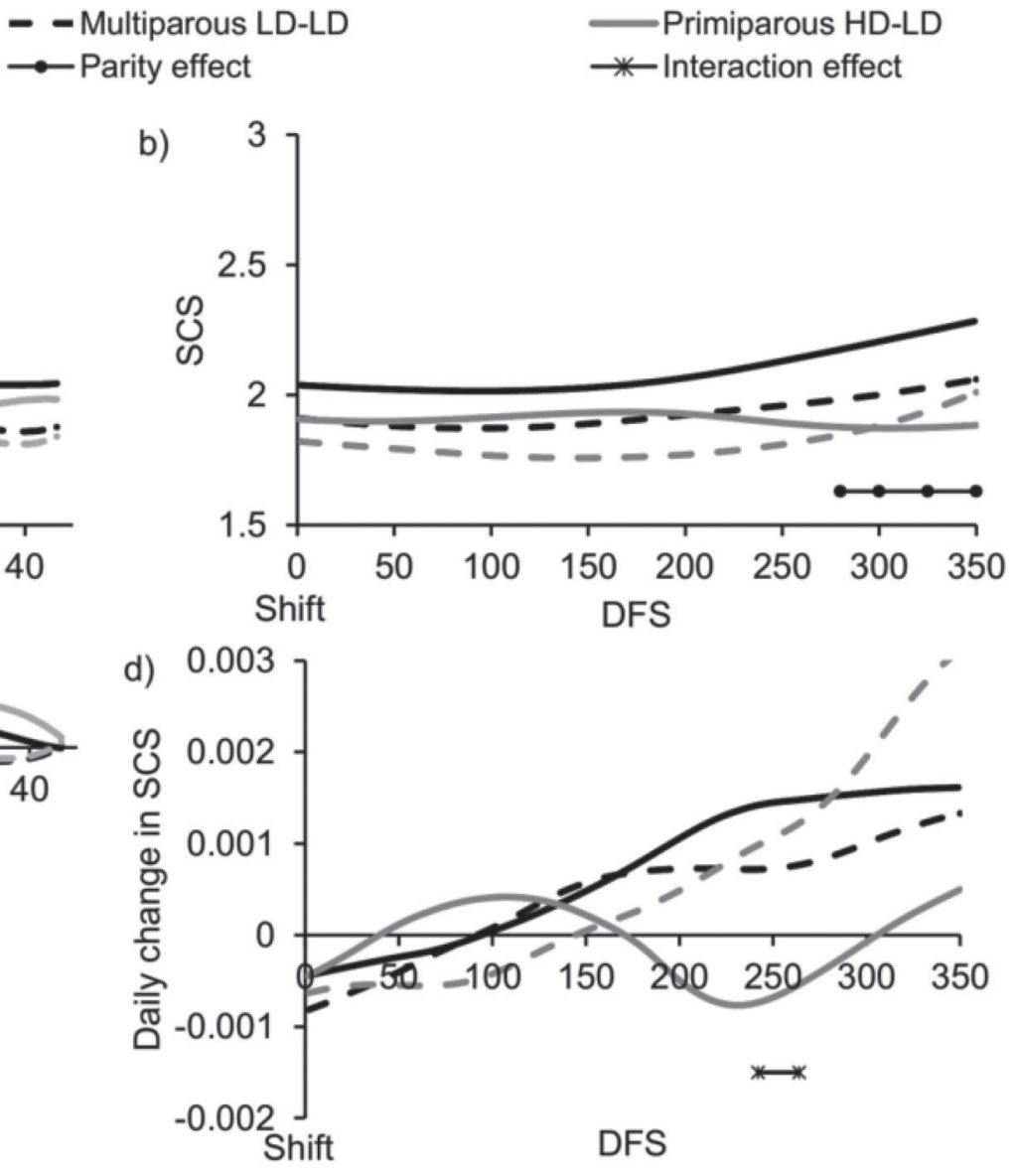

Figure 6. Smoothed SCS and associated slopes from calving to 42 DIM (a and c, respectively), and after the shift back to a common diet for all cows [days from shift (DFS) $=0$ ] until 350 DFS (b and d, respectively), according to treatment (full line HD-LD, dash line LD-LD) and parity (black multiparous, gray primiparous). The days on which the effects of treatment, parity, and their interaction are significant $(P<0.05)$ are indicated by the horizontal bars on the graphs. LD-LD = group with 1 partially mixed ration 60:40 forage:concentrate during the entire lactation. HD-LD = group with 2 partially mixed rations 50:50 followed by 60:40 forage:concentrate when live weight gain $\geq 0$ and at least after 42 DIM. 
to the end of the lactation, the SCS was higher for the multiparous cows compared with the primiparous cows. There was no effect of treatment on the SCS for this period and no differences on the slopes between groups or parities (Figure 6).

$\boldsymbol{B} \boldsymbol{C S}$ and $\boldsymbol{L} \boldsymbol{W}$. For the whole postshift period, both parities had the same BCS (Figure 7), and the primiparous cows were lighter than multiparous cows regardless of the treatment (Figure 8). The shapes of the LW and BCS curves were similar between the LD-LD and HD-LD cows. From 150 to 350 DFS, the primiparous cows had a slower increase of BCS than the multiparous cows.

Feed and Energy Intake. The DMI of the primiparous cows was lower than the DMI of the multiparous cows. The interaction effect with DMI found for the first 50 DFS indicated that the multiparous HD-LD cows ate more than the multiparous LD-LD cows, whereas the primiparous HD-LD cows ate less than the primiparous LD-LD cows. From 20 DFS to the end of the lactation, only the parity affected the shape of the DMI curves. The results for the net energy intake followed the DMI results (Figure 9).

Energy Balance. From 0 to 350 DFS, the EB increased for both groups (Figure 10); no effect of treatment on EB was observed. From 0 to 50 DFS the EB of the LD-LD cows increased faster than the EB of the HD-LD cows, and from 230 to 300 DFS the EB of the HD-LD cows increased faster than the $\mathrm{EB}$ of the LD-LD cows.

\section{Complementary Results}

Reproduction. More cows expressed mounting behavior at 8 mo than at 2 mo after calving, the feeding
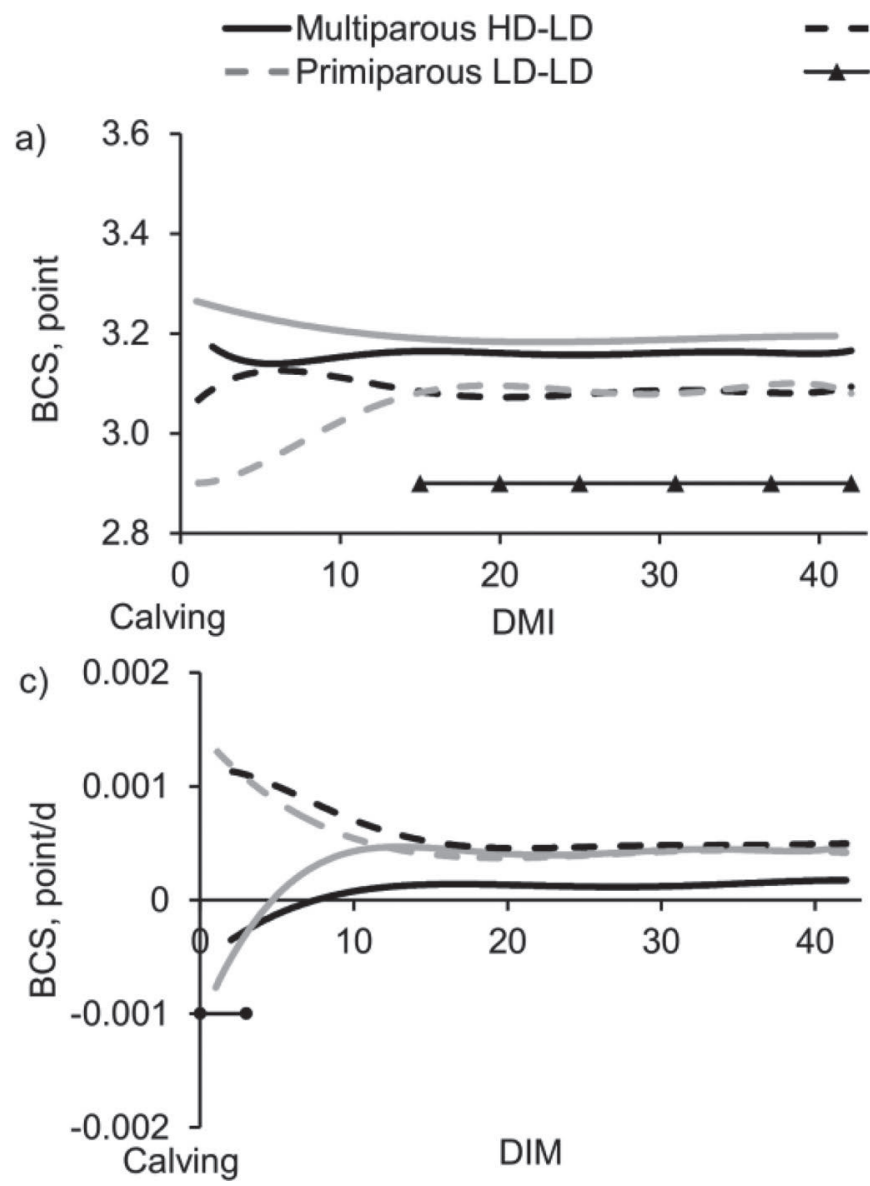
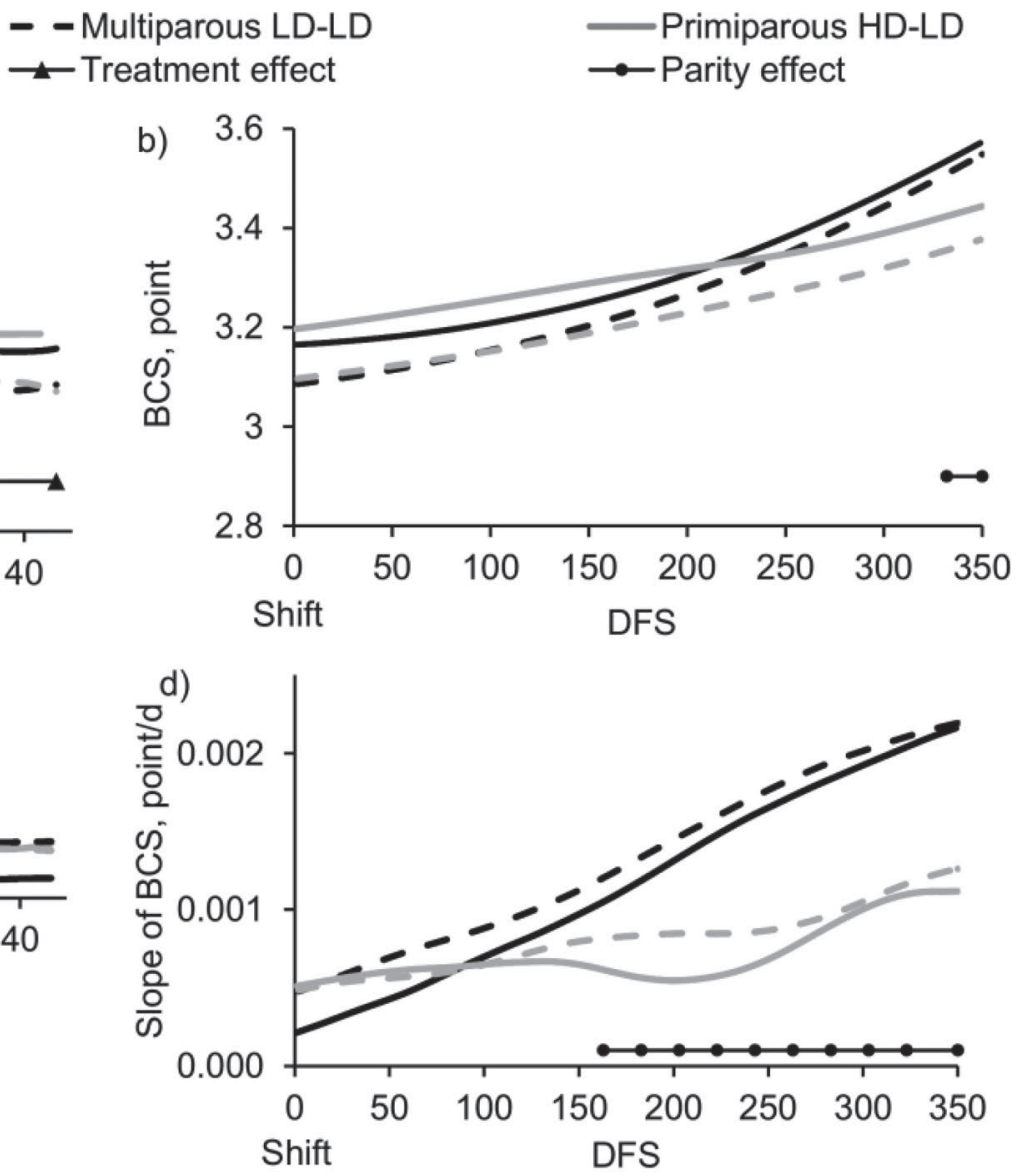

Figure 7. Smoothed BCS (points) and associated slopes from calving to 42 DIM (a and c, respectively), and after the shift back to a common diet for all cows [days from shift (DFS) =0] until 350 DFS (b and d, respectively), according to treatment (full line HD-LD, dash line LD-LD) and parity (black multiparous, gray primiparous). The days on which the effects of treatment, parity, and their interaction are significant ( $P$ $<0.05)$ are indicated by the horizontal bars on the graphs. LD-LD = group with 1 partially mixed ration $60: 40$ forage:concentrate during the entire lactation. HD-LD $=$ group with 2 partially mixed rations 50:50 followed by 60:40 forage:concentrate when live weight gain $\geq 0$ and at least after 42 DIM. 
treatment had no effect on pregnancy rates $(40 \%$ at first insemination; Gaillard et al., 2016), and the conception rates and number of inseminations were similar for the 16-mo lactation and the previous and following 10-mo lactations (C. Gaillard, J. Sehested, and M. Vestergaard, AU Foulum, Tjele, Denmark, unpublished data).

Duration of the Mobilization Period. After the shift in diet (shift day on average at 50 DIM) and until 36 wk after calving, the plasma nonesterified fatty acids were higher for the HD-LD cows than for the LD-LD cows, indicating that the HD-LD cows sustain the mobilization for a longer period of time than the LD-LD cows (Gaillard et al., 2015).

\section{DISCUSSION}

\section{Mobilization Period (From Calving Until Day of Diet Shift)}

Group Characteristics. The treatment had no effect on the milk yield or ECM of primiparous cows before the shift in diet. The results indicate that the groups LD-LD and HD-LD of primiparous cows were not well balanced with respect to yield potential. Indeed, the milk production of the LD-LD primiparous was higher than that of the HD-LD primiparous the first days following calving, and the difference was the same at 42 DIM (i.e., around $4 \mathrm{~kg}$ milk more per day

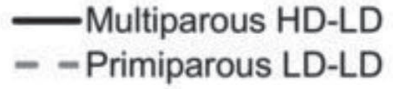

a)
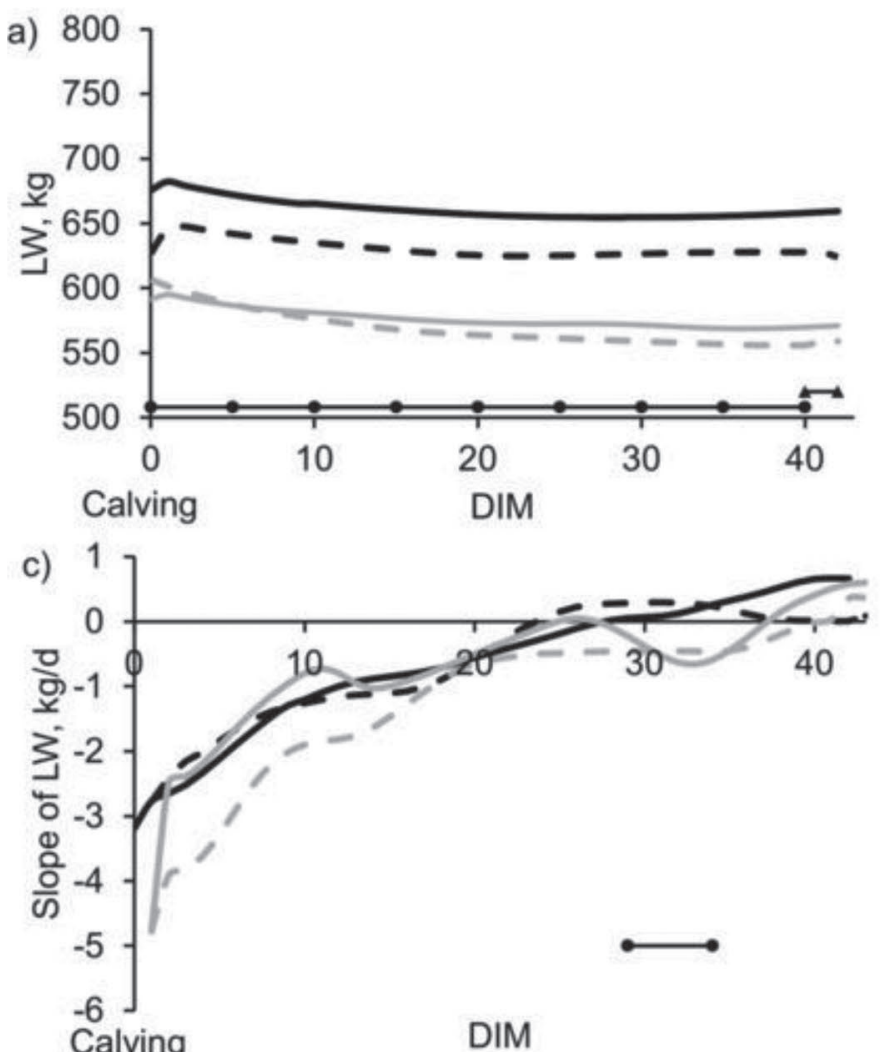

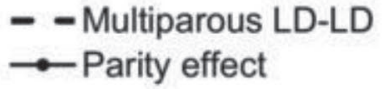

-Primiparous HD-LD

$\rightarrow$ Treatment effect
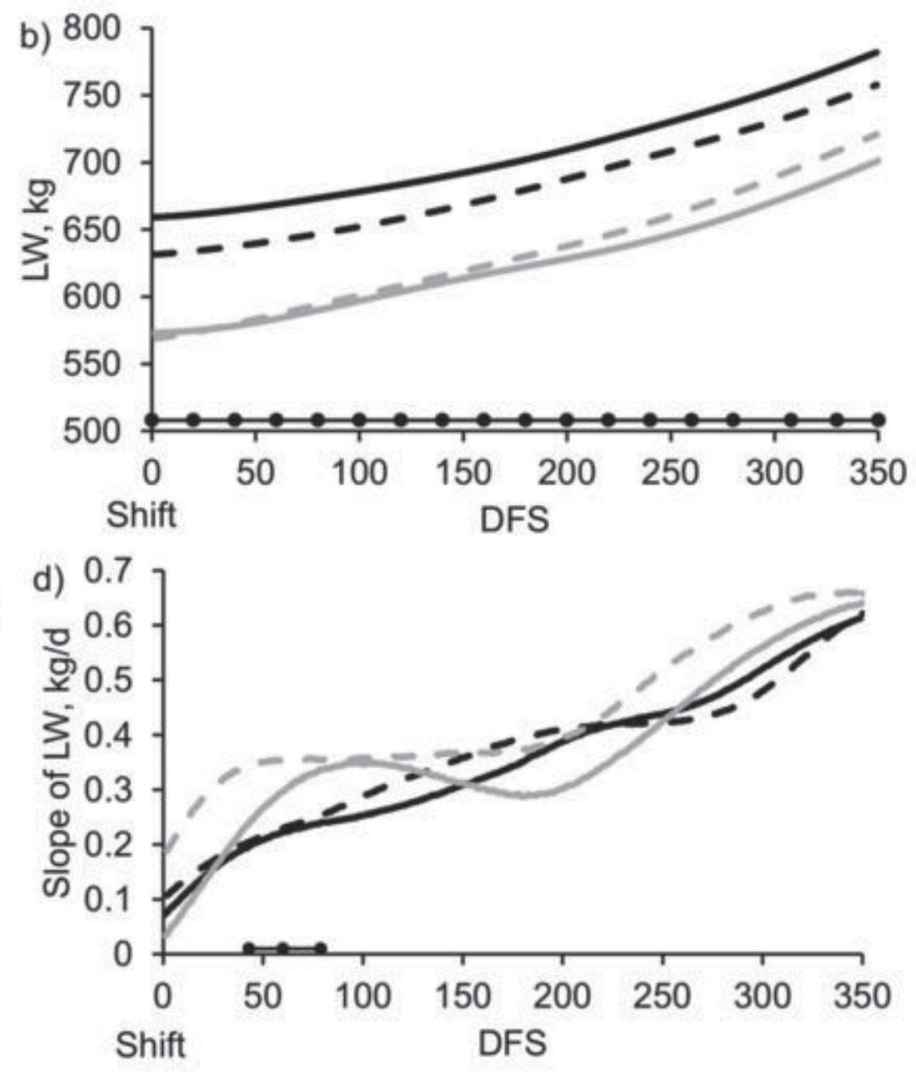

Figure 8. Smoothed live weight (LW; kg/d) and associated slopes from calving to 42 DIM (a and c, respectively), and after the shift back to a common diet for all cows [days from shift (DFS) =0] until 350 DFS (b and d, respectively), according to treatment (full line HD-LD, dash line LD-LD) and parity (black multiparous, gray primiparous). The days on which the effects of treatment, parity, and their interaction are significant $(P<0.05)$ are indicated by the horizontal bars on the graphs. LD-LD = group with 1 partially mixed ration 60:40 forage:concentrate during the entire lactation. HD-LD = group with 2 partially mixed rations 50:50 followed by 60:40 forage:concentrate when LW gain $\geq 0$ and at least after 42 DIM. 
for LD-LD). However, blocking according genetic potential was not possible due to multiple sires. For the multiparous cows, the groups LD-LD and HD-LD were well balanced regarding milk potential as indicated by similar milk production right after calving. At around 42 DIM, the HD-LD multiparous cows produced around $4 \mathrm{~kg}$ milk more per day than the LD-LD multiparous indicating the effect of the feeding treatment.

Use of Extra Feed Energy. Before 42 DIM, the energy intake of the HD-LD cows was higher than that of the LD-LD cows, whereas DMI was unaffected by treatment. For the multiparous cows, this extra energy was used for both milk and body reserves. The HD-LD cows lost less weight during the mobilization period than the LD-LD cows and, consequently, had a higher LW at the end of the period than the LD-LD cows; this is in accordance with previous studies (Andersen et al., 2004; Bossen and Weisbjerg, 2009; Machado et al., 2014). For the primiparous cows, the extra energy was only used for growth and body reserves, but not to increase the milk yield. This is in accordance with Bossen et al. (2009), one of the rare studies presenting result on primiparous cows, where feeding a higher energy density had no significant effect on the primiparous milk yield but a positive effect on the multiparous milk yield.

\section{Carryover Effect of Energy Feeding in Early Lactation}

After the mobilization period, all cows received the same diets. The treatment had few small carryover

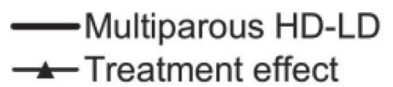

- - Multiparous LD-LD
$\rightarrow$ - Parity effect

a)

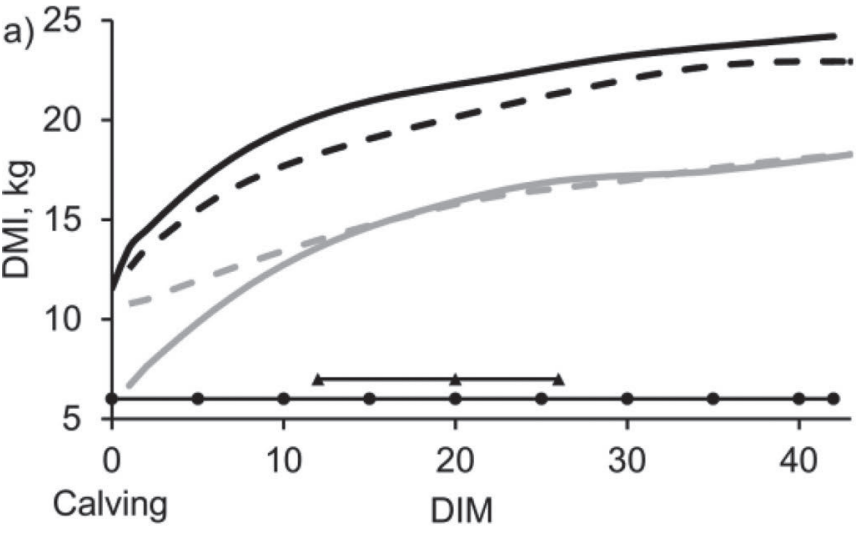

c)

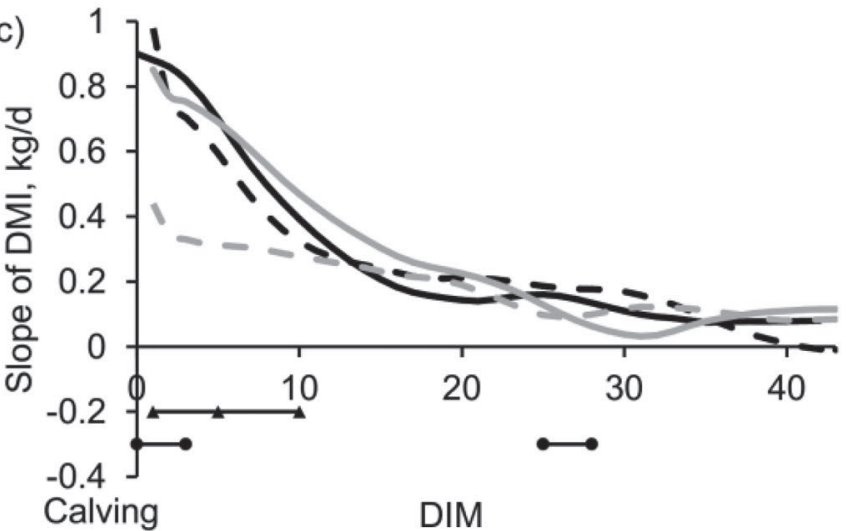

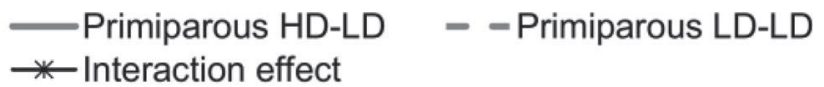

b)
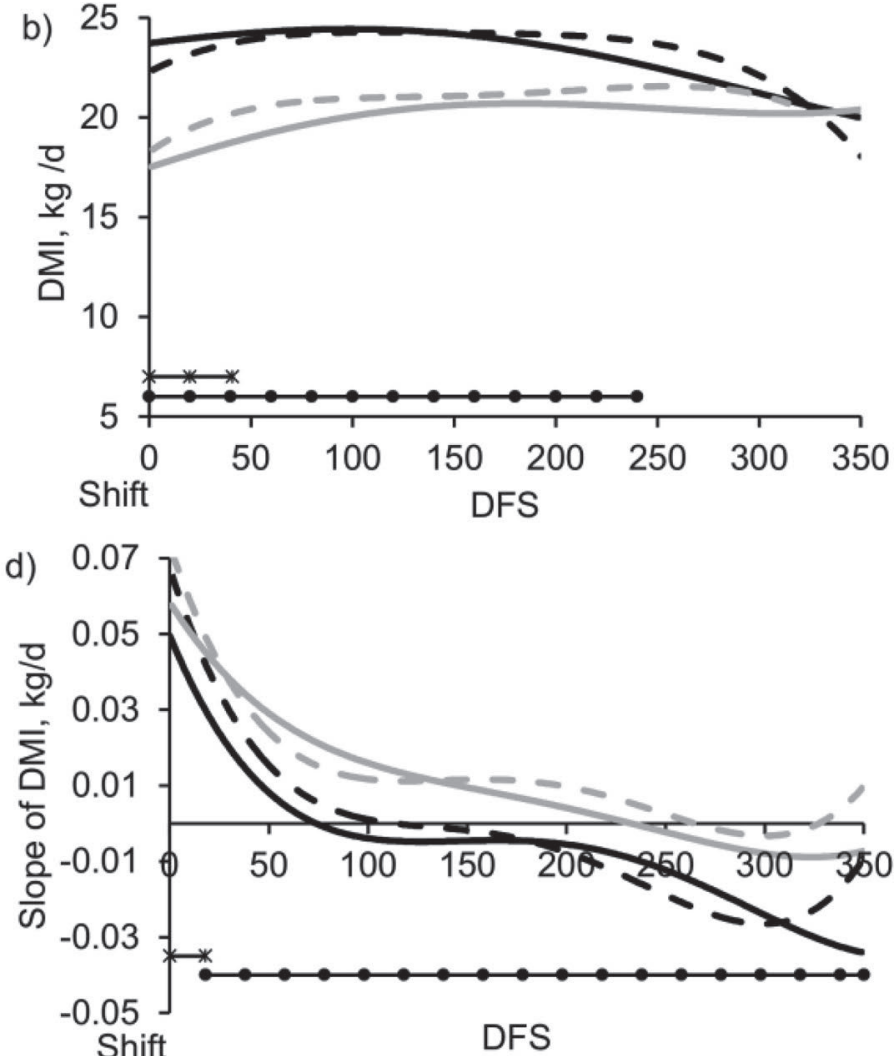

Figure 9. Smoothed DMI (kg/d) and associated slopes from calving to 42 DIM (a and c, respectively), and after the shift back to a common diet for all cows [days from shift (DFS) $=0$ ] until 350 DFS (b and d, respectively), according to treatment (full line HD-LD, dash line LD-LD) and parity (black multiparous, gray primiparous). The days on which the effects of treatment, parity, and their interaction are significant ( $P$ $<0.05)$ are indicated by the horizontal bars on the graphs. LD-LD = group with 1 partially mixed ration 60:40 forage:concentrate during the entire lactation. HD-LD $=$ group with 2 partially mixed rations 50:50 followed by 60:40 forage:concentrate when live weight gain $\geq 0$ and at least after 42 DIM. 
effects after the shift, whereas the shapes of several curves were different right after the shift and at the end of the lactation.

Short-Term Carryover. During the $50 \mathrm{~d}$ following the diet shift, DMI, and consequently energy intake, of HD-LD was higher than LD-LD for multiparous cows. This indicates a short-term carryover effect of energy feeding in early lactation. The higher intake immediately postshift explains the small increase of milk production for the multiparous HD-LD compared with the multiparous LD-LD observed for the 8 first days following the shift. The slopes of fat and lactose also reflect this difference of energy intake between LD-LD and HD-LD for the $50 \mathrm{~d}$ following the shift. These short-term carryover effects were expected as part of the adaptation period for cows changing diet. Bossen et al. (2009) also found a reduced milk yield right after the change from an energy enriched diet to a lower-energy diet. They also indicated that this short-term effect was stabilized after $2 \mathrm{wk}$, as in the present experiment. In general, milk reduction is affected by the stage of the lactation: the earlier the change to a lower-energy diet is introduced, the smaller is the reduction (Bossen et al., 2009). However, it should be noted that this effect was not seen in primiparous cows, which is probably due to their pretrial differences in milk production levels.

Long-Term Carryover. As can be seen from the significant effects of treatment (and treatment interactions) in late lactation, there were long-term carry-over effects of energy feeding in early lactation on milk composition (Figure 2). Postshift lactose in milk for the HD-LD cows was lower and decreased faster than for the LD-LD cows. The fat in milk of the HD-LD cows was lower for the multiparous and higher for the primiparous than for the LD-LD cows. These results are in accordance with Dessauge et al. (2011), who found a
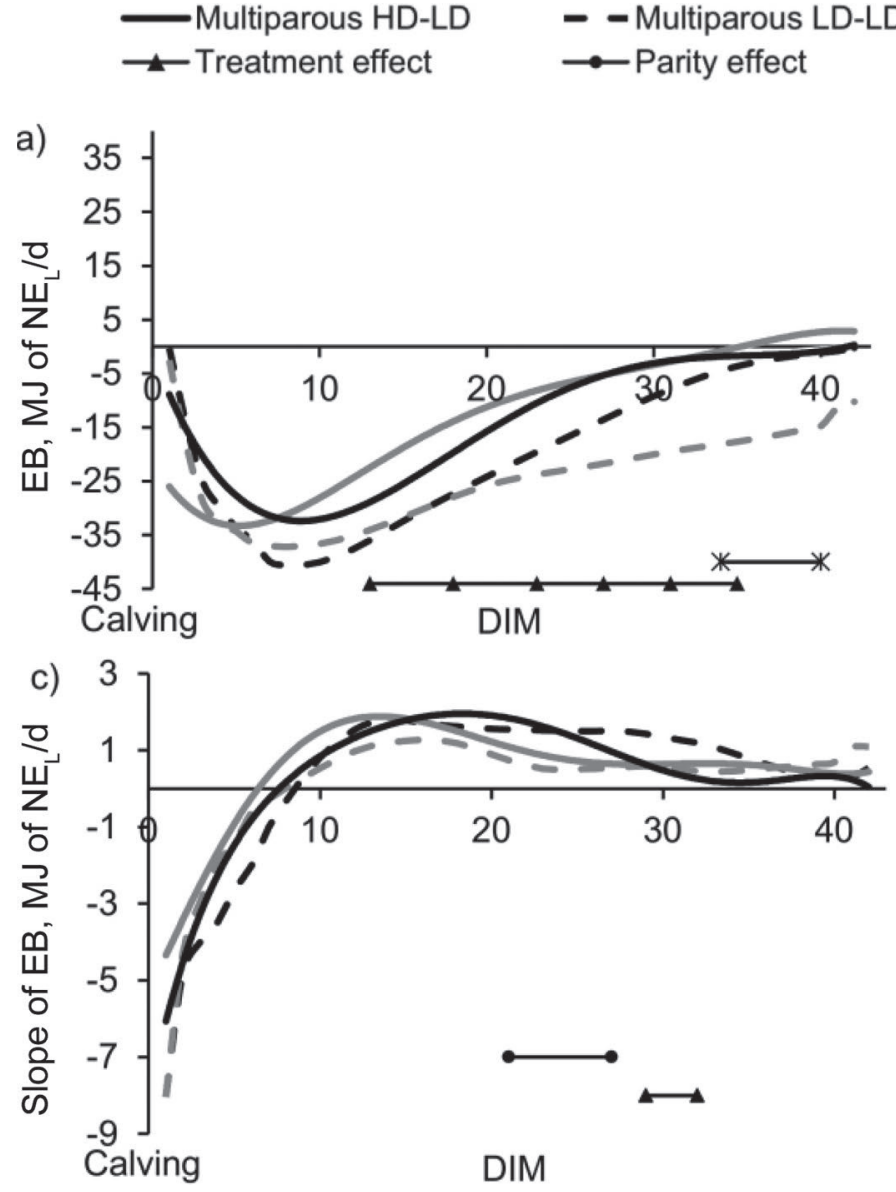

$\rightarrow$ Parity effect
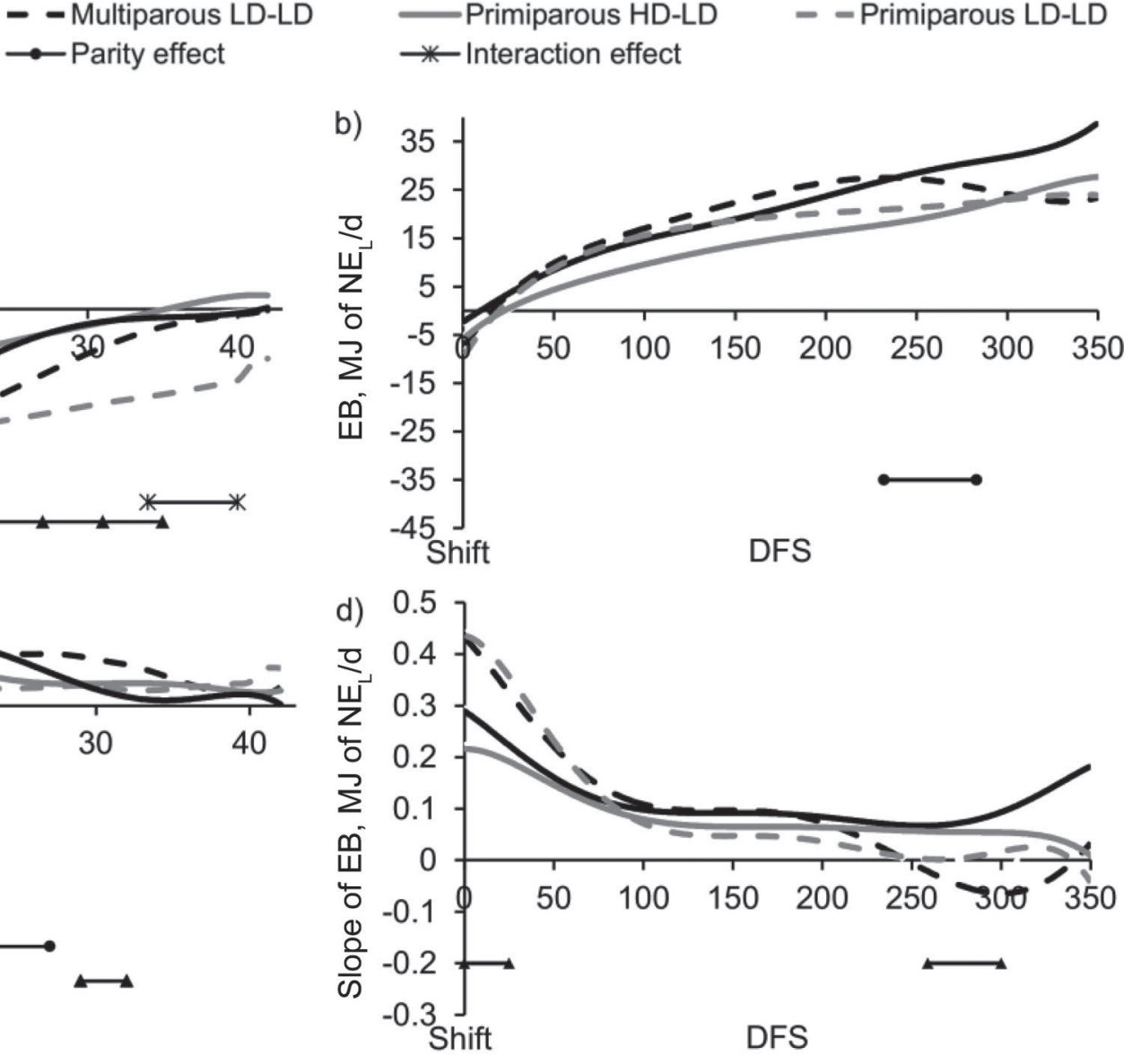

Figure 10. Smoothed energy balance (EB; $\mathrm{MJ}$ of $\mathrm{NE}_{\mathrm{L}} / \mathrm{d}$ ) and associated slopes from calving to 42 DIM (a and c, respectively), and after the shift back to a common diet for all cows [days from shift (DFS) $=0$ ] until 350 DFS (b and d, respectively), according to treatment (full line HD-LD, dash line LD-LD) and parity (black multiparous, gray primiparous). The days on which the effects of treatment, parity, and their interaction are significant $(P<0.05)$ are indicated by the horizontal bars on the graphs. LD-LD = group with 1 partially mixed ration 60:40 forage:concentrate during the entire lactation. HD-LD = group with 2 partially mixed rations 50:50 followed by 60:40 forage:concentrate when live weight gain $\geq 0$ and at least after 42 DIM. 
decline of lactose and fat in milk when the cows where fed restrictively.

At the end of the period, from 250 to 350 DFS, the ECM dropped faster for the HD-LD cows than for the LD-LD cows. This late carryover effect was unexpected given that carryover effects on ECM appear to diminish rapidly during the first $50 \mathrm{~d}$ postshift. Days in milk at which pregnancy started were compared between the groups to make sure that this late decrease of persistency was not due to an earlier pregnancy for the HD-LD cows. The results indicated that the time of pregnancy was similar between the groups LD-LD and HD-LD (246 and $240 \pm 8.8$ DIM, respectively; $P=0.27$; Table $2)$. Moreover, at insemination time, cows were fed the same diet and had similar DMI. Thus, the late difference observed on persistency between the LD-LD and HD-LD cows can be considered as a negative long-term carryover of the early treatment.

Feeding an energy-enriched diet in early lactation has been found to increase the mid-lactation milk yield for cows managed for 10 mo of lactation (Bossen et al., 2009); thus, we were expecting a similar long-term effect, including an increase in persistency, after returning to a lower-energy diet. However, studies have also shown that the positive effect of a high-energy diet in early lactation is often counterbalanced by a reduced milk yield persistency when the diet energy is reduced (Everson et al. 1976; Cassel et al., 1984). In the present experiment with extended lactation, no mid-lactation increase in milk production was noted, but there was a decrease in persistency at the end of lactation. This negative long-term effect on persistency might be due to an increase of apoptosis of the epithelial cells of the mammary glands as well as a decrease of cell proliferation, as it has been found that an energy restriction during lactation negatively affects mammary cell proliferation (Dessauge et al., 2011). In this context, our shift to a lower-energy diet can be considered as a restriction in energy that may lead to a decrease in cell proliferation of the mammary gland and, thus, could explain the decrease of persistency observed in late lactation.

\section{CONCLUSIONS}

Feeding an energy-enriched diet in early lactation reduced the intensity of the mobilization period independently of parity, as it reduced weight loss. The energy-enriched diet also increased the milk production of multiparous cows. This dietary treatment had a little short-term carryover on the production data when cows returned to the control diet, and had a negative longterm carryover effect on lactation persistency, which was significant from $250 \mathrm{~d}$ from diet shift.

\section{ACKNOWLEDGMENTS}

The authors thank The Danish Council for Strategic Research, The Programme Commission on Health, Food and Welfare (Copenhagen, Denmark) for the financial support for this experiment. We acknowledge the staff at the Danish Cattle Research Centre (Foulum, Denmark) for their highly committed effort to run the experiment. We acknowledge the technicians Connie $\mathrm{H}$. Middelhede and Martin Bjerring (AU Foulum, Tjele, Denmark) for their effective efforts to bring about data.

\section{REFERENCES}

Andersen, J. B., N. C. Friggens, T. Larsen, M. Vestergaard, and K. L. Ingvartsen. 2004. Effect of energy density in the diet and milking frequency on plasma metabolites and hormones in early lactation dairy cows. J. Vet. Med. A Physiol. Pathol. Clin. Med. 51:52-57.

AOAC International. 2000. Official Methods of Analysis. 17th ed. AOAC Int., Washington, DC.

Borman, J. M., K. L. Macmillan, and J. Fahey. 2004. The potential for extended lactations in Victorian dairying: a review. Aust. J. Exp. Agric. 44:507-519.

Bossen, D., and M. R. Weisbjerg. 2009. Allocation of feed based on individual dairy cow live weight changes II: Effect on milk production. Livest. Sci. 126:273-285.

Bossen, D., M. R. Weisbjerg, L. Munksgaard, and S. Hojsgaard. 2009. Allocation of feed based on individual dairy cow live weight changes I: Feed intake and live weight changes during lactation. Livest. Sci. 126:252-272.

Cassel, E. K., W. G. Merrill, R. A. Milligan, and R. W. Guest. 1984. Evaluation of systems for feeding supplemental concentrate to cows in groups. J. Dairy Sci. 67:560-568.

Dessauge, F., V. Lollivier, B. Ponchon, R. Bruckmaier, L. Finot, S. Wiart, E. Cutullic, C. Disenhaus, S. Barbey, and M. Boutinaud. 2011. Effects of nutrient restriction on mammary cell turnover and mammary gland remodeling in lactating dairy cows. J. Dairy Sci. 94:4623-4635.

European Community. 2012. First commission directive 71/250/EEC establishing Community methods of analysis for the official control of feeding-stuffs-15 June 1971. Accessed Nov. 24, 2015. http:// faolex.fao.org/cgi-bin/faolex.exe?rec_id=027228\&database=faole $\mathrm{x} \&$ search_type=link\&table=result\&lang=eng\&format_name=@ ERALL.

Everson, R. A., N. A. Jorgensen, J. W. Crowley, E. L. Jensen, and G. P. Barrington. 1976. Input-output of dairy cows fed a complete ration of constant or variable forage to grain ratio. J. Dairy Sci. 59:1776-1787.

Ferguson, J. D., D. T. Galligan, and N. Thomsen. 1994. Principal descriptors of body condition score in Holstein cows. J. Dairy Sci. 77:2695-2703.

Friggens, N. C., P. Berg, P. Theilgaard, I. R. Korsgaard, K. L. Ingvartsen, P. Lovendahl, and J. Jensen. 2007. Breed and parity effects on energy balance profiles through lactation: Evidence of genetically driven body energy change. J. Dairy Sci. 90:5291-5305.

Gaillard, C., H. Barbu, M. T. Sørensen, J. Sehested, H. Callesen, and M. Vestergaard. 2016. Milk yield and estrous behavior during eight consecutive estruses in Holstein cows fed standardized or high energy diets and grouped according to live weight changes in early lactation. J. Dairy Sci. http://dx.doi.org/10.3168/jds.2015-10023.

Gaillard, C., M. Vestergaard, M. R. Weisbjerg, and J. Sehested. 2015 Effects of live weight adjusted feeding strategy on plasma indicators of energy balance in Holstein cows managed for extended lactation. Animal. http://dx.doi.org/10.1017/S175173111500258X.

Grossman, M., and W. J. Koops. 2003. Modeling extended lactation curves of dairy cattle: A biological basis for the multiphasic approach. J. Dairy Sci. 86:988-998. 
Hansen, B. 1989. Determination of nitrogen as elementary N, an alternative to Kjeldahl. Acta Agric. Scand. 39:113-118.

Knight, C. H. 2005. Extended lactation: Turning theory into reality. Adv. Dairy Tech. 17:113-123.

Knudsen, K. E. B., P. Aman, and B. O. Eggum. 1987. Nutritive value of Danish grown barley varieties. 1. Carbohydrates and other major constituents. J. Cereal Sci. 6:173-186.

Laird, N. M., and J. H. Ware. 1982. Random effects models for longitudinal data. Biometrics 38:963-974.

Løvendahl, P., and M. Bjerring. 2006. Detection of carryover in automated milk sampling equipment. J. Dairy Sci. 89:3645-3652.

Machado, S. C., C. M. McManus, M. T. Stumpf, and V. Fischer. 2014. Concentrate:forage ratio in the diet of dairy cows does not alter milk physical attributes. Trop. Anim. Health Prod. 46:855-859.

Mertens, D. R., M. Allen, J. Carmany, J. Clegg, A. Davidowicz, M Drouches, K. Frank, D. Gambin, M. Garkie, B. Gildemeister, D. Jeffress, C. S. Jeon, D. Jones, D. Kaplan, G. N. Kim, S. Kobata, D. Main, X. Moua, B. Paul, J. Robertson, D. Taysom, N. Thiex, J. Williams, and M. Wolf. 2002. Gravimetric determination of amylase-treated neutral detergent fiber in feeds with refluxing in beakers or crucibles: Collaborative study. J. AOAC Int. 85:1217-1240.

Nørgaard, J., A. Sørensen, M. T. Sørensen, J. B. Andersen, and K. Sejrsen. 2005. Mammary cell turnover and enzyme activity in dairy cows: Effects of milking frequency and diet energy density. J. Dairy Sci. 88:975-982.

NRC. 2001. Nutrient Requirements of Dairy Cattle. Natl. Acad. Press, Washington, DC.

Pettersson, G., K. Svennersten-Sjaunja, and C. H. Knight. 2011. Relationships between milking frequency, lactation persistency and milk yield in Swedish Red heifers and cows milked in a voluntary attendance automatic milking system. J. Dairy Res. 78:379-384.
Pinheiro, J., D. Bates. S. DebRoy, D. Sarkar, and RC Team. 2015 nlme: Linear and Nonlinear Mixed Effects Models [Internet]. R package version 3.1-119. Accessed Aug. 5, 2015. http://CRAN.Rproject.org $/$ package $=$ nlme.

R Development Core Team. 2015. R: A language and Environment for Statistical Computing. Version 3.0.0. R Foundation for Statistical Computing, Vienna, Austria. Accessed Dec. 23, 2015. http:// www.r-project.org.

Ramsay, J. O., G. Hooker, and S. Graves. 2010. Functional Data Analysis with R and Matlab, Springer, New York, NY.

Sjaunja, L. O., L. Baevre, L. Junkkarinen, J. Pedersen, and J. Setala. 1991. A Nordic proposal for an energy corrected milk (ECM) formula. Pages 156-157 in Performance Recording of Animals - State of the Art 1990. EAAP Publication 50. P. Gaillon and Y. Chabert, ed. Centre for Agricultural Publishing and Documentation (PUDOC), Wageningen, the Netherlands.

Sorensen, A., D. D. Muir, and C. H. Knight. 2008. Extended lactation in dairy cows: Effects of milking frequency, calving season and nutrition on lactation persistency and milk quality. J. Dairy Res. 75:90-97.

Sorensen, M. T., J. V. Nørgaard, P. K. Theil, M. Vestergaard, and K. Sejrsen. 2006. Cell turnover and activity in mammary tissue during lactation and the dry period in dairy cows. J. Dairy Sci. 89:4632-4639.

Volden, H. 2011. NorFor - The Nordic feed evaluation system. EAAP Publications No 130. Wageningen Academic Publishers, Wageningen, the Netherlands.

Wood, P. D. P. 1967. Algebraic model of lactation curve in cattle. Nature 216:164-165. 